\title{
Endocannabinoid System in Hepatic Glucose Metabolism, Fatty Liver Disease, and Cirrhosis
}

\author{
Ivonne Bazwinsky-Wutschke ${ }^{1, \dagger}$, Alexander Zipprich ${ }^{2, \dagger}$ and Faramarz Dehghani $1, *($ C) \\ 1 Department of Anatomy and Cell Biology, Martin Luther University Halle-Wittenberg, \\ Grosse Steinstrasse 52, D-06108 Halle (Saale), Germany; ivonne.bazwinsky@medizin.uni-halle.de \\ 2 Laboratory of Molecular Hepatology, Clinic of Internal Medicine I, Martin Luther University \\ Halle-Wittenberg, Ernst-Grube-Strasse 40, D-06120 Halle (Saale), Germany; \\ alexander.zipprich@medizin.uni-halle.de \\ * Correspondence: faramarz.dehghani@medizin.uni-halle.de; Tel.: +49-345-5571-707; Fax: +49-345-5571-700 \\ + These authors contributed equally to this work.
}

Received: 30 April 2019; Accepted: 19 May 2019; Published: 22 May 2019

check for updates

\begin{abstract}
There is growing evidence that glucose metabolism in the liver is in part under the control of the endocannabinoid system (ECS) which is also supported by its presence in this organ. The ECS consists of its cannabinoid receptors (CBRs) and enzymes that are responsible for endocannabinoid production and metabolism. ECS is known to be differentially influenced by the hepatic glucose metabolism and insulin resistance, e.g., cannabinoid receptor type $1\left(\mathrm{CB}_{1}\right)$ antagonist can improve the glucose tolerance and insulin resistance. Interestingly, our own study shows that expression patterns of CBRs are influenced by the light/dark cycle, which is of significant physiological and clinical interest. The ECS system is highly upregulated during chronic liver disease and a growing number of studies suggest a mechanistic and therapeutic impact of ECS on the development of liver fibrosis, especially putting its receptors into focus. An opposing effect of the CBRs was exerted via the $\mathrm{CB}_{1}$ or $\mathrm{CB}_{2}$ receptor stimulation. An activation of $\mathrm{CB}_{1}$ promoted fibrogenesis, while $\mathrm{CB}_{2}$ activation improved antifibrogenic responses. However, underlying mechanisms are not yet clear. In the context of liver diseases, the ECS is considered as a possible mediator, which seems to be involved in the synthesis of fibrotic tissue, increase of intrahepatic vascular resistance and subsequently development of portal hypertension. Portal hypertension is the main event that leads to complications of the disease. The main complication is the development of variceal bleeding and ascites, which have prognostic relevance for the patients. The present review summarizes the current understanding and impact of the ECS on glucose metabolism in the liver, in association with the development of liver cirrhosis and hemodynamics in cirrhosis and its complication, to give perspectives for development of new therapeutic strategies.
\end{abstract}

Keywords: endocannabinoid system; hepatic cannabinoid receptors; G protein-coupled receptor (GPR)119; GPR55; peroxisome proliferator-activated receptor (PPAR)

\section{Introduction}

The endocannabinoid system (ECS) is a complex physiological system that affects metabolic pathways in the brain and in peripheral organs [1]. The ECS comprises cannabinoid receptors (CBRs), their endogenous ligands, termed endocannabinoids, and the enzymes involved in the endocannabinoid synthesis and degradation [2-5].

Cannabinoids are a class of plant derived or synthetic compounds, including the herbal cannabinoids that occur in the cannabis plant (Cannabis sativa) or synthetic analogs that might or might not act on classical CBRs [4]. The endogenously produced counterparts are termed as endocannabinoids. 
Endocannabinoids are synthesized "on demand" from long-chain polyunsaturated fatty-acids and act on cells in paracrine or autocrine manner [2,6]. The first-discovered and best-studied endocannabinoids are anandamide ( $\mathrm{N}$-arachidonoyl-ethanolamine, AEA) and 2-arachidonoylglycerol (2-AG). Newly proposed endocannabinoids such as 2-arachidonyl-glyceryl ether (noladin, 2-AGE), $\mathrm{O}$-arachidonoyl-ethanolamine (virodhamine), or $\mathrm{N}$-arachidonoyl-dopamine have been isolated, although their physiological functions are only partly understood [4]. Anandamide is a ligand for the CBRs type 1 and $2\left(\mathrm{CB}_{1}, \mathrm{CB}_{2}\right)$, however, it is functionally selective for the $\mathrm{CB}_{1}$ and can interact with non-classic $\mathrm{CBRs}$ such as the transient receptor potential vanilloid type 1 (TRPV1) receptor [7] or the nuclear receptors peroxisome proliferation-activated receptor (PPAR) $\alpha$ and PPAR $\gamma$ at high micromolar concentrations [8,9]. 2-AG is a ligand for the $\mathrm{CB}_{1}$ and $\mathrm{CB}_{2}$ receptors und is generally produced from the hydrolysis of 2-arachidonate-containing diacylglycerols. AEA synthesis is under the control of a selective calcium-dependent phospholipase D namely $\mathrm{N}$-arachidonoyl-phosphatidylethanolamine-phospholipase D (NAPE-PLD) whereas the fatty-acid amide hydrolase (FAAH) catalyzes the hydrolysis of anandamide, and to a certain extent 2-AG. 2-AG is formed by two diacylglycerol lipases $\alpha$ and $\beta$ (DAGL $\alpha$ and $\beta$ ) and hydrolyzed by the monoacylglycerol lipase (MAGL). Another way to degrade AEA and 2-AG involve oxidation via cyclooxygenase-2 (COX-2) [10-12]. Considering the CBRs, amongst the numerous CBRs, the most investigated are the $\mathrm{CB}_{1}$ and $\mathrm{CB}_{2}$ receptors which belong to members of the superfamily of $G$ protein-coupled receptors (GPCRs). The $\mathrm{CB}_{1}$ receptor (or CNR1) was originally cloned from rat cerebral cortex [13] and its identity as a $C B R$ was subsequently revealed [14]. The $\mathrm{CB}_{2}$ receptor (or CNR2) was first cloned from rat spleen [15]. Its distinct actions from the $\mathrm{CB}_{1}$ were confirmed after the creation of $\mathrm{CB}_{2}$ receptor-deficient mice [16]. Besides the classical $\mathrm{CB}_{1}$ and $\mathrm{CB}_{2}$ receptors, other deorphanized GPCRs such as GPR3, GPR6, GPR18, GPR55, and GPR119 and non-cannabinoid receptors, like the TRPV1, or the peroxisome proliferator-activated receptors (PPARs), are suggested as part of the endocannabinoid system [5,17].

\section{Expression of Cannabinoid Receptors $\mathrm{CB}_{1}$ and $\mathrm{CB}_{2}$}

Cannabinoid receptor type $1\left(\mathrm{CB}_{1}\right)$ and type $2\left(\mathrm{CB}_{2}\right)$ are known to be highly abundant in the central nervous system $\left(\mathrm{CB}_{1}\right.$ : [18-20], $\mathrm{CB}_{2}$ : [21-23]). Both receptors were also identified in peripheral organs, including the liver [24-28]. Earlier studies have investigated the presence of the ECS in peripheral organs and found conflicting results. Most of these studies denied the presence of $C_{1}$ and $C B_{2}$ in the non-pathological liver [29-33]. However, more recent studies have demonstrated $\mathrm{CB}_{1}$ - and $\mathrm{CB}_{2}-\mathrm{mRNA}$ expression in normal human liver tissue [34]. Recently, it is widely accepted that both receptors are present in liver tissue. Accordingly, $\mathrm{CB}_{1}$ and $\mathrm{CB}_{2}$ mediate a number of biological functions in different types of liver cells, including hepatocytes, stellate cells, and sinusoidal endothelial cells [35]. The main cannabinoid receptor found in liver cells is the $\mathrm{CB}_{1}$ receptor. It was detected in hepatic sinusoidal cells, stellate cells and hepatocytes, whereas the $C_{2}$ receptor was identified in Kupffer cells and stellate cells [36-40]. Interestingly, a novel human $C_{1}$ receptor isoform $\left(\mathrm{CB}_{1 \mathrm{~b}}\right)$ has been found to be highly expressed in pancreatic $\beta$-cells and hepatocytes, but not in the brain [40]. Both $\mathrm{CB}_{1}$ and $\mathrm{CB}_{2}$ receptors signal through $\mathrm{G}_{\mathrm{i} / 0}$ proteins, inhibit adenylyl cyclase and regulate ion channels e.g., rectifying potassium channels or voltage-gated calcium channels [41], although there is also evidence that $\mathrm{CB}_{1}$ can act via $G_{s}$ proteins. The activity of a variety of intracellular kinases, e.g., mitogen activated protein kinases and extracellular signal-regulated kinases (MAPK/ERK pathway), c-Jun N-terminal kinases (JNKs), and protein kinase B (Akt) are regulated by CBRs.

Similar to other GPCRs, the intracellular C-terminal domain of $\mathrm{CB}_{1}$ receptor mediates its effects into different signaling pathways, such as protein kinase A (PKA), mitogen-activated protein kinases (MAPKs), etc. The proximal C-terminal domain represented by amino acids 401-417 is essential for protein-protein interactions. The distal C-terminal tail domain represented by amino acids 418-472 determines the magnitude and kinetics of intracellularly induced signals [42-44]. 


\subsection{Diurnal Expression of Hepatic Cannabinoid Receptors $C B_{1}$ and $C B_{2}$}

In view of hepatic $\mathrm{CB}_{1}$ and $\mathrm{CB}_{2}$ expression, we have been able to show a diurnal expression pattern of $\mathrm{CB}_{1}$ and $\mathrm{CB}_{2}$ mRNA in liver tissue of young and middle-aged normoglycemic Wistar rats. The diurnal mRNA expression was followed accordingly by comparable translation levels of CB1 receptor protein [45]. The same study revealed that diurnal expression levels of cannabinoid receptors are influenced by the diabetic state of the rats. The animals showed alterations in their diurnal profile of both receptors in streptozotocin-treated 12- and 51-week-old or normoglycemic rats [45]. Interestingly, higher levels of cannabinoid receptors during the light period and decreased expression levels during darkness might be seen in relation to results on a rhythmic expression pattern of the vast majority of hepatic genes driven by food intake [46].

In accordance to this phenomenon, mice showed a bimodal rhythm with a major peak during early evening and a minor peak in the late night [46]. Feeding induced metabolic regulators, which in turn drive rhythmic transcription, in addition to the transcriptional output of the hepatic circadian clock [46]. For example, $\mathrm{CB}_{1}$ regulates the metabolic and stress regulators $\mathrm{cAMP}$-response element-binding protein (CREB) and sterol regulatory element binding protein (SREBP).

The activation of $\mathrm{CB}_{1}$ in mice increased the hepatic gene expression of the lipogenic transcription factor SREBP-1c and its targets acetyl-CoA carboxylase-1 (ACC) and fatty acid synthase (FAS) [25]. In the same study, treatment with a $\mathrm{CB}_{1}$ agonist increased the de novo fatty acid (FA) synthesis in the liver and in isolated hepatocytes. Another study demonstrated a novel mechanism of activated $\mathrm{CB}_{1}$, which was able to induce hepatic gluconeogenesis via direct activation of cAMP-responsive element-binding protein $\mathrm{H}$ (CREBH) [47]. CREBH functions as a circadian-regulated liver transcriptional regulator that integrates energy metabolism with the circadian rhythm [48]. It was further shown that via CREBH, 2-AG treatment significantly induced hepatic gene expression levels of the key gluconeogenic enzymes PEPCK (phosphoenolpyruvate carboxykinase) and G6pc (glucose-6-phosphatase catalytic subunit) in primary rat hepatocytes, causing a significant increase in glucose production in hepatocytes [49]. It is noteworthy that in mice at the end of the subjective day increased expression of phosphoenolpyruvate carboxykinase 1 (transcript) and Glut-2 (transcript and protein) were observed, and hepatic metabolic genes such as glucokinase and pyruvate kinase showed their peaks of transcripts during the subjective night [50]. Diurnal variations of mRNA levels of lipogenic enzymes were also demonstrated in rat liver [51]. The key lipogenic enzymes fatty acid synthetase (FAS), acetyl-CoA-carboxylase (ACC), and adenosine triphosphate (ATP)-citrate lyase showed diurnal variations by reaching their maximum activity at night and minimum during light periods [52]. Therefore, the diurnal rhythm of cannabinoid receptors is seemingly related to food intake since this is associated with rhythmic expression of the vast majority of hepatic genes of lipid and glucose metabolism [46].

\subsection{Cannabinoid Receptor $C B_{1}$ - and $C B_{2}$-Function and Its Metabolic Consequences in the Liver}

Based on the reported increase of both anandamide and $\mathrm{CB}_{1}$ receptor levels in the liver it has been suggested, that during an early stage of high-fat-induced obesity, the hepatic ECS can be activated [53]. In fact, there was an increase of $\mathrm{CB}_{1}$ receptor levels in the livers of wild-type mice fed with a high-fat diet (HFD) for 3 weeks when compared to wild-type mice fed with a normal diet. $\mathrm{CB}_{1}$ receptor-null mice developed significantly less fat mass compared to wild-type mice [26]. An explanation of the underlying mechanism is provided by Liu et al. [54]. The activation of liver $\mathrm{CB}_{1}$ receptors by endocannabinoids has been shown to trigger downstream pathways of insulin resistance. One of these target enzymes involved in the progression of insulin resistance is the stearoyl-CoA desaturase-1 (SCD1). It generates monounsaturated fatty acids (MUFAs) which have the ability to inhibit fatty acid amide hydrolase, and by that, promoting increased hepatic levels of anandamide in obese mice (DIO). It is therefore concluded, that the hepatic endocannabinoid/ $\mathrm{CB}_{1}$ receptor system is intertwined with SCD1. The upregulation of one, causes a positive feedback loop which ultimately adds to lipogenesis and insulin resistance in obese mice [54]. As a consequence of administering a HFD, increased hepatic fatty acid (FA) synthesis was displayed, as well as the development of a hepatic steatosis phenotype. 
However, these symptoms were blunted by rimonabant and were absent in $\mathrm{CB}_{1}{ }^{-/-}$knockout mice [55]. $\mathrm{CB}_{1}$ activation increased FA synthesis in normal mice, an effect that was not observed in $\mathrm{CB}_{1}$ knockout mice [56]. The activation of the $\mathrm{CB}_{1}$ receptor affects the fat metabolism in the liver by increasing lipogenic gene expression, de novo FA synthesis [25] and lipogenic enzyme activity [57].

Treatment of cultured mouse liver explants with rimonabant increased fat oxidation, whereby, showing that hepatic $C_{1}$ inverse agonism reduced the expression of genes for prolipogenic enzymes [58].

$\mathrm{CB}_{1}$-mediated increase in glycogenolysis and/or gluconeogenesis resulted in increased hepatic glucose production [12]. In line with the previous results, hepatic glucose production was decreased during peripheral infusion of the $\mathrm{CB}_{1}$ antagonist rimonabant in diet-induced obese rats [59].

In addition to $\mathrm{CB}_{1}, \mathrm{CB}_{2}$-signaling may also contribute significantly to the mechanisms that regulate lipid accumulation as shown in immortalized human hepatocytes and HepG2 cells [60]. Accordingly, $\mathrm{CB}_{2}$ direct agonists may enhance the expression of $\mathrm{CB}_{1}$, thereby amplifying the downstream effects on lipid metabolism, resulting in an increased lipid accumulation within the hepatocyte [60]. High-fat diet-induced hepatic steatosis was enhanced in wild-type mice treated with $\mathrm{CB}_{2}$ agonist (6aR,10aR)-3-(1,1-Dimethylbutyl)-6a,7,10,10a-tetrahydro-6,6,9-trimethyl-6H-dibenzo[b,d]pyran (JWH-133) and blunted in $\mathrm{CB}_{2}$ receptor knockout mice [39].

\subsection{Cannabinoid Receptor $C B_{1}$ - and $C B_{2}$-Agonism/Antagonism in Metabolic Disorders of the Liver}

Steatosis essentially is described as the abnormal retention of lipids in the liver. It is caused by malfunctioning of lipid synthesis, catabolism, and transport from/to the liver. The inflammatory processes involved in steatosis are often also associated with obesity and insulin resistance. Persisting inflammatory processes lead to non-alcoholic steatohepatitis (NASH) and fibrosis, which can progress into more severe stages such as cirrhosis [61]. Chronic overfeeding often results in hepatic lipid accumulation, thereby exceeding the triglyceride storage capacity of hepatocytes. This effect causes the activation of apoptotic and inflammatory pathways, with the development of insulin resistance as a consequence.

Rimonabant, $\mathrm{aCB}_{1}$ inverse agonist, has an anti-lipogenic effect in the human hepatocyte cell line (HepG2) by inhibiting liver $\mathrm{X}$ receptor- $\alpha(\mathrm{LXR} \alpha)$-dependent SREBP-1c induction. This is mediated by an increase in PKA activity, a protein kinase involved in lipid metabolism, and PKA-mediated liver kinase $\mathrm{B} 1$ (LKB1) activation downstream of $\mathrm{CB}_{1}$-coupled $\mathrm{G} \alpha(\mathrm{i} / \mathrm{o})$ inhibition [62]. Blocking $\mathrm{CB}_{1}$ has an impact on carbohydrate and lipid metabolism, which was successfully shown in hepatocytes collected from both lean and obese $(o b / o b)$ mice. Its effects were the upregulation of genes involved in these metabolisms and interestingly enough, could be reversed when treated with an agonist. It caused a decline in essential hepatic lipogenic proteins [63]. Another study supported these findings and indicated that solely peripherally active $\mathrm{CB}_{1}$ inverse agonists/antagonists had therapeutic potential in obesity because of their high efficacy in normalizing the related metabolic abnormalities, including insulin resistance and fatty liver [64].

Obesity-associated hepatic steatosis and dyslipidemia were also significantly reversed in Zucker $(f a / f a)$ rats after 8 weeks of treatment with $\mathrm{CB}_{1}$ specific antagonist, suggesting a direct peripheral effect on carbohydrate and lipid metabolism after blocking $\mathrm{CB}_{1}$ in the liver. In addition, chronic treatment with rimonabant reduced obesity-associated hepatic steatosis [65].

Administration of $\mathrm{CB}_{1}$ antagonists to obese mice showed favorable effects on the phenotype of liver steatosis, including lipid parameters. The improvement of visceral adipose tissue metabolism via $\mathrm{CB}_{1}$ antagonism was reported as a determining factor for the normalization of plasma parameters and the reversion of liver steatosis [66]. In liver explants obtained from both lean and ob/ob mice, blocking the $\mathrm{CB}_{1}$ improved both carbohydrate and lipid metabolism indicating a strong differential influence of hepatic $\mathrm{CB}_{1}$ receptor [58,66]. This has been supported by Liu et al. [67] who have reported that endocannabinoids contributed to diet-induced insulin resistance in mice via hepatic $\mathrm{CB}_{1}$-mediated inhibition of insulin signaling and clearance. Furthermore, $\mathrm{CB}_{1}$ activation was involved 
in the pathogenesis of obesity-related hypertriglyceridemia which underscored the potential efficacy of $\mathrm{CB}_{1}$ antagonists in treating metabolic disease [68].

Using a diet-induced obesity (DIO) mouse model, $\mathrm{CB}_{1}$ receptor antagonist SR14176 treatment over 5 weeks induced a transient reduction of food intake and a noticeable but sustained reduction of body weight and adiposity. The drug lowered plasma leptin, insulin, and free fatty acid levels. The $\mathrm{CB}_{1}$ antagonist SR141716 did not exert the same effects in $\mathrm{CB}_{1}$ knockout mice supporting the observation of crucial $\mathrm{CB}_{1}$ receptor activity [56]. Indeed, hepatic $\mathrm{CB}_{1}$ receptor is involved in development of diet-induced steatosis, dyslipidemia, and insulin and leptin resistance [69]. Notably, $\mathrm{CB}_{1}{ }^{-1-}$ mice were resistant to HFD $[25,56]$, whereas liver-specific $\mathrm{CB}_{1}$ knockout mice developed obesity in similar pattern and intensity as wild-type mice [69]. However, the liver-specific $\mathrm{CB}_{1}$ knockout mice showed less steatosis, hyperglycemia, dyslipidemia, and insulin and leptin resistance compared to wild-type mice fed with a HFD. These findings indicated that endocannabinoid mediated activation of hepatic $\mathrm{CB}_{1}$ receptors contributes to the diet-induced steatosis and associated hormonal and metabolic changes, but not to the increase in adiposity, observed with high-fat diet [69].

Interestingly, aging seems to have an influence on the cannabinoid receptor-mediated effects [70]. $\mathrm{CB}_{1}$-antagonism improved glucose tolerance and enhanced liver insulin sensitivity in aged, but not young, adult mice. A key role for $\mathrm{CB}_{1}$ in age-related insulin resistance and metabolic dysfunction has been highlighted, with $\mathrm{CB}_{1}$ blockade as a potential strategy for combating metabolic disorders associated with aging [70].

It should be mentioned, that both $\mathrm{CB}_{1}$ and $\mathrm{CB}_{2}$ played a role in the proper functioning of the lipid metabolism in human-derived immortalized hepatocytes. Genes targeted by both receptors included essential enzymes involved in lipid synthesis and transport [60]. Knocking out the gene for $\mathrm{CB}_{2}$ resulted in improved insulin sensitivity when investigating age-related or diet-induced insulin resistance. Whereby, demonstrating an important role of $\mathrm{CB}_{2}$ in glucose metabolism by modulating skeletal muscle insulin sensitivity and the inflammatory response in the adipose tissue [71].

Taken together, animal studies as well as human studies have suggested that especially blocking $\mathrm{CB}_{1}$ in the liver has a direct peripheral effect on carbohydrate and lipid metabolism (Figure 1). Fatty liver is strongly associated with insulin resistance, increased hepatic glucose production and impaired glucose tolerance in humans [72,73]. Rimonabant was the first, and up until now, the only agent to be approved for the control of obesity because of its body-weight-reducing effects in laboratory animals and man [74]. It was initially considered as a novel therapeutic option for NASH [75], by decreasing fatty liver, increasing hepatic insulin sensitivity, and decreasing hepatic glucose production [76]. However, rimonabant was removed from the market shortly after its introduction in Europe because of severe psychiatric side effects [74]. The development of non-centrally active specific antagonists for $\mathrm{CB}_{1}$ isoforms and additionally selective for hepatocytes [40] would be an attractive alternative for the treatment of metabolic liver diseases. 


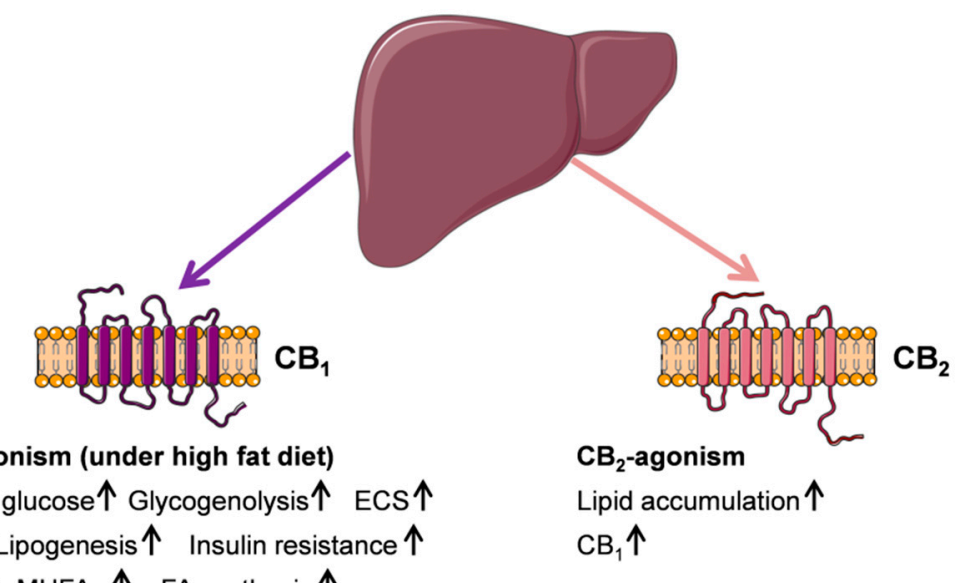

$\mathrm{CB}_{1}$-agonism (under high fat diet)

Hepatic glucose $\uparrow$ Glycogenolysis $\uparrow$ ECS $\uparrow$

$\mathrm{CB}_{1} \uparrow$ Lipogenesis $\uparrow$ Insulin resistance $\uparrow$

Lipid accumulation $\uparrow$

SCD1 $\uparrow$ MUFAs $\uparrow$ FA synthesis $\uparrow$

Gluconeogenesis $\uparrow$ Hepatic steatosis $\uparrow$

$\mathrm{CB}_{2}$-antagonism/deficiency

Lipogenic gene expression and enzyme activity $\uparrow$

Insulin sensitivity $\uparrow$

$\mathrm{CB}_{1}$-antagonism/deficiency

Fat mass $\downarrow$ FA synthesis $\downarrow$ Hepatic steatosis $\downarrow$

Fat oxidation $\uparrow$ Genes for prolipogenic enzymes $\downarrow$

Hepatic glucose $\downarrow$

Figure 1. Schematic illustration of cannabinoid receptor (CBR) function in liver metabolism. ( $\uparrow$ ) and $(\downarrow)$ define up or down regulation. Most findings were generated in rodent models. This figure was prepared using a template on the Servier Medical Art website (Available at: http://smart.servier.com/).

\section{Other Hepatic Cannabinoid Receptors in Metabolism and Metabolic Disorders of the Liver}

\subsection{G Protein-Coupled Receptor 55 (GPR55)}

In addition to $\mathrm{CB}_{1}$ and $\mathrm{CB}_{2}$ receptors, several deorphanized GPCRs are present in the liver. Recent studies revealed that some cannabinoids and non-cannabinoid ligands bound to the protein of $G$ protein-coupled receptor 55 (GPR55) [77-80] which might act as a novel "type-3 (CB3)" cannabinoid receptor [81], despite the fact that this receptor does not appear to share a similar fingerprint with any of the classical cannabinoid receptors [82].

GPR55 belongs to the group $\delta$ of the rhodopsin-like (class A) family of GPCRs and showed low sequence identity to both $\mathrm{CB}_{1}$ and $\mathrm{CB}_{2}[5,78,83]$. GPR55 is suspected to be a possible CBR. It occurs in various tissues regulating energy homeostasis, such as the hypothalamus, gastrointestinal tract, pancreas, liver, white adipose tissue, and the skeletal muscle. Recent studies have demonstrated GPR55 mRNA and protein expression in the liver of rodents and humans [84-86]. Accordingly, lysophosphatidylinositol (LPI), an endogenous ligand of GPR55, was abundantly found in the periphery, e.g., high absolute amounts of the major LPI species were quantified in the liver, suggesting an important role in activating GPR55 for the corresponding organ $[87,88]$.

However, the (patho)physiological role of GPR55 in cell dysfunction is still poorly understood, mainly because of the limited identification of downstream signaling targets [86]. Different agonists for GPR55 activated different signaling pathways [86], however, the signaling pathways of this receptor in liver tissue are unknown until now. A current study has shown that GPR55 deficiency in mice was associated with increased obesity, reduced physical activity and energy expenditure. Adipose tissue, liver, and skeletal muscle exhibited a significant reduction in insulin signaling capacity, which may be a consequence of tissue-specific changes in phosphatase and tensin homolog (PTEN) and insulin receptor substrate 1(IRS-1) expression [89]. In accordance, central and peripheral administration of GPR55 agonist O-1602 stimulated food intake in the short-term and increased obesity in the long-term [90]. Another study indicated that the LPI/GPR55 system could be positively associated with obesity in humans [85]. 
Interestingly, it was further demonstrated that GPR55- and $\mathrm{CB}_{1}$-receptor signaling was modulated if receptors are co-expressed, forming a heteromer in vitro. GPR55 signaling was inhibited in the presence of $\mathrm{CB}_{1}$ receptors. In contrast, $\mathrm{CB}_{1}$ receptor-mediated signaling was enhanced if GPR55 was co-expressed [77]. GPR55 has also been demonstrated to interact with $\mathrm{CB}_{2}$ in immune cells [91]. Such crosstalk between GPR55 and $\mathrm{CB}_{2}$ signaling might also occur in tissues where both $\mathrm{CB}_{2}$ and GPR55 are co-expressed in metabolically active tissues, including the liver, which could have implications for hepatic glucose metabolism [86]. Subsequent high throughput assays have identified GPR55 ligands to not belong to the family of cannabinoids. They also did not bind to either $\mathrm{CB}_{1}$ or $\mathrm{CB}_{2}$ [92].

\subsection{G Protein-Coupled Receptor (GPR119)}

GPR119 belongs to the group of deorphanized GPCRs and has, although phylogenetically related to CBRs, shown to interact solely with fatty acid amides $[5,93,94]$. It is present (mRNA and protein) in human and mouse liver tissue as well as in primary mouse hepatocytes [95]. Increased levels of key lipogenic enzymes (FAS, ACC, and SCD1), but not of gluconeogenic enzymes phosphoenolpyruvate carboxykinase and pyruvate carboxylase (PEPCK and PC, respectively-), were observed in hepatocytes isolated from GPR119 knockout mice compared to wild-type mice. In hepatocytes, GPR119 regulated the hepatic lipogenesis by stimulation of 5'-adenosine monophosphate-activated protein kinase (AMPK) phosphorylation [95]. AMPK phosphorylation suppressed SREB-1 expression, which in turn reduced the expression of lipogenic enzymes, including FAS, ACC, and SCD1, thereby inhibiting hepatic lipid accumulation. Conclusively, ligands of GPR119 attenuated hepatic steatosis by inhibiting SREBP-1-mediated lipogenesis $[95,96]$. Recent results have demonstrated strong in vivo evidence for protection against development of fatty liver by GPR119 agonist APD668 (4-[[1-[2fluoro-4-(methylsulfonyl)phenyl]-1H-pyrazolo[3,4-d]pyrimidin-4-yl]oxy]-1-piperidinecarboxylic acid,1-methylethyl ester) in a mouse model of NASH. This drug was able to reduce metabolic risk factors such as increased levels of circulating cholesterol, glucose, and triglyceride levels as well as hepatic injury markers. Once fully tested, APD668 might be used in the treatment of non-alcoholic fatty liver disease (NAFLD) or NASH in the future [97].

In mice fed a high trans-fat diet to induce steatohepatitis, monotherapy with either APD668 or linagliptin caused a reduction in the levels of alanine aminotransferase, aspartate aminotransferase, glucose, cholesterol, and epididymal fat mass. These effects were more pronounced upon treatment with a combination of both drugs. On the other hand, combined treatment of APD668 and linagliptin showed a non-significant additive effect in reduction of hepatic triglyceride [98]. Figure 2 gives a summary of GPR55 and GPR119 functions. 


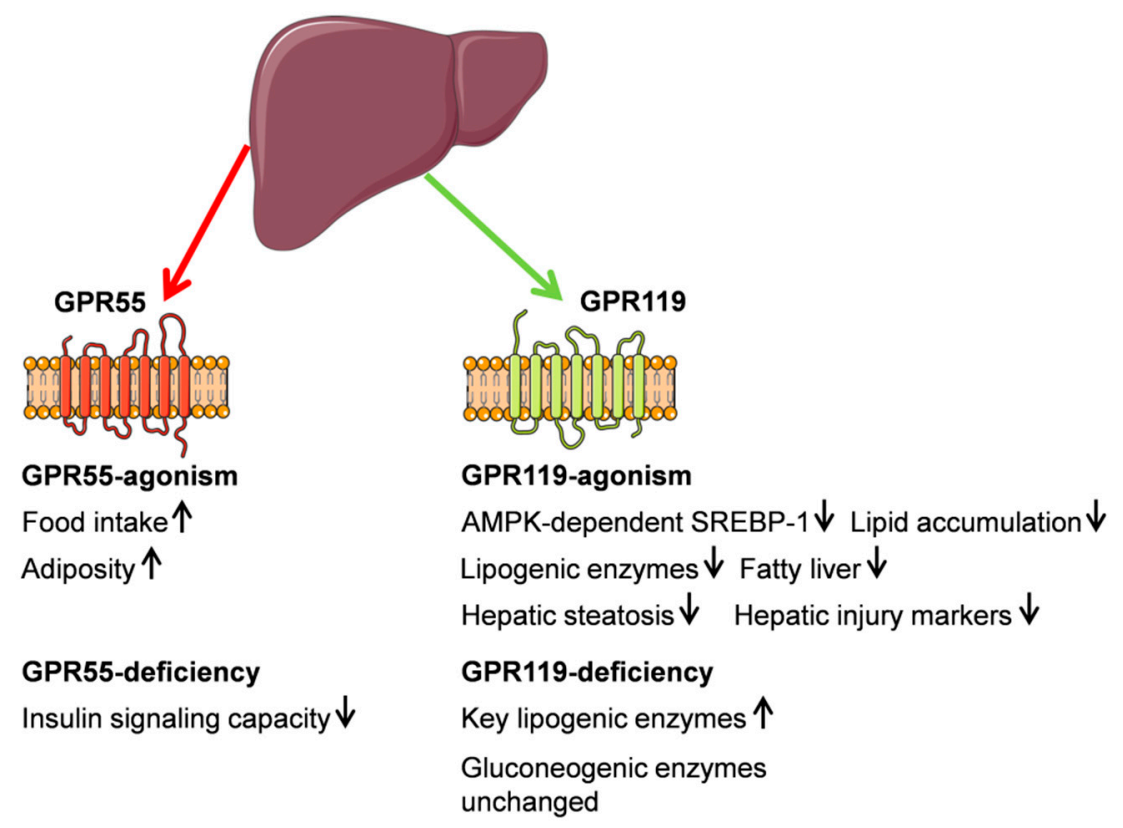

Figure 2. Schematic illustration of G protein-coupled receptor (GPR) function in liver metabolism. $(\uparrow)$ and $(\downarrow)$ define up or down regulation. Most findings were generated in rodent models. This figure was prepared using a template on the Servier Medical Art website (Available at: http://smart.servier.com/).

\section{Peroxisome Proliferator-Activated Receptors (PPARs)}

PPARs are highly important transcription factors that are activated by numerous synthetic and endogenous ligands. Once activated, they regulate the transcription of downstream target genes [99]. Nuclear receptors, activated under physiological and pathological conditions, are considered as the new target for endocannabinoids [100]. Some cannabinoids activate the different isoforms of PPARs, as shown through the use of reporter gene assays, binding studies, selective antagonists, and knockout studies [101]. PPARs participate in regulating genes involved in fatty acid uptake and oxidation, lipid and carbohydrate metabolism, inflammation, and cell proliferation in general [102,103].

PPARs belong to the family of ligand-activated transcription factors, playing a key role in regulating adipogenesis and inhibiting liver fibrosis [104]. The PPAR $\alpha$ (NR1C1), PPAR $\beta / \delta$ (NR1C2), and $P P A R \gamma$ (NR1C3) genes share a highly conserved sequence encoding for proteins with high similarity in structure and function [99]. Interestingly, from these known isotypes, each of them has liver cell-type specific patterns of expression (e.g., PPAR $\alpha, \operatorname{PPAR} \beta / \delta$ in hepatocytes, PPAR $\gamma$ in hepatic stellate cells) [104].

\subsection{PPAR $\alpha$}

PPAR $\alpha$ has shown to play a critical role in modulation of energy balance and regulation of hepatic lipid metabolism and acted to reduce hepatic intracellular FA concentrations $[105,106]$. Indeed, in the liver, PPAR $\alpha$ was found mostly in hepatocytes where it prevented triglyceride accumulation $[107,108]$, whereas relative mRNA expression was very low in endothelial cells and Kupffer cells [109]. PPAR $\alpha$ was found to stimulate the oxidation of fatty acids on a cellular level in various organelles, such as mitochondria, peroxisomes, and microsomes, as well as the uptake of fatty acids and the synthesis of lipoproteins in hepatocytes. Therefore, it seems to be mainly involved in the fatty acid metabolism [102]. PPAR $\alpha$ transcriptionally upregulated numerous genes that are involved in mitochondrial and peroxisomal fatty acid oxidation and in phospholipid remodeling [110,111].

In addition, PPAR $\alpha$ affected the duration of an inflammatory response induced by dihydroxy fatty acid leukotriene $\mathrm{B}_{4}\left(\mathrm{LTB}_{4}\right)$ [112]. PPAR $\alpha$ activation impaired the IL-6 signaling pathway in the liver at 
the level of membrane receptors and the level of transcription factors [113], and therefore participated in the downregulation of hepatic inflammatory processes.

The main effects of PPAR $\alpha$ overexpression or PPAR ligands in the mice liver included a decreased inflammation, increased FA uptake and FA oxidation, decreased very-low-density lipoprotein (VLDL) production, increased high-density lipoprotein (HDL) apolipoproteins, and decreased acute phase reactants [106].

PPAR $\alpha$ activated antioxidant enzymes and suppressed hepatic fibrosis in rats [114]. PPAR $\alpha$ ligands had an antifibrotic action in the rat thioacetamide (TAA) model of liver cirrhosis, probably due to an antioxidant effect of enhanced catalase expression and activity in the liver. Fatty acid metabolism and ketogenesis are the most conserved PPAR $\alpha$-regulated biological processes in mice and humans, while the glycolysis-gluconeogenesis pathway by PPAR $\alpha$ agonists occurred in mice, but not in men [115]. In human hepatocytes, PPAR $\alpha$ agonism specifically controlled xenobiotic metabolism and apolipoprotein synthesis pathways. PPAR $\alpha$ activation lead to increased $\beta$-oxidation rates by fibroblast growth factor 21 (FGF21) activation to provide substrates for ketone body synthesis and gluconeogenesis, thus maintaining energy sources for peripheral tissues [115]. Oleoylethanolamide (OEA) is a natural fatty acid ethanolamide that acted through the activation of PPAR $\alpha$ and decreased neutral lipid content in hepatocytes as well as serum cholesterol and triglyceride levels [116]. Further studies have demonstrated that OEA in low and high micromolar concentrations exerted a pharmacological effect by modulating hepatic fibrosis development through the inhibition of hepatic stellate cell (HSC) activation and therefore may be a potential therapeutic agent against liver fibrosis. These results have suggested that endogenous PPAR $\alpha$ agonist OEA effectively suppressed activation of HSCs and liver fibrosis through the effects on transforming growth factor (TGF)- $\beta 1$ [117]. Taken together, studies using mouse models and pharmacological treatments have demonstrated a beneficial effect of PPAR $\alpha$ by preventing steatosis, inflammation, and fibrosis. Preclinical as well as clinical studies have shown an impact of PPAR $\alpha$ on NAFLD and NASH development [118-122]. PPAR $\alpha$ knockout mice fed a HFD seemingly have an increased susceptibility to NASH, as shown by more advanced steatosis and increased markers of oxidative stress and inflammation [118]. Another study implicating a role of PPAR $\alpha$ in lipid homeostasis has shown that this nuclear receptor has a sexual dimorphism which causes gender specific alterations in the levels of circulating lipids, in the fat storage and obesity phenotype [119].

Hepatocyte-restricted PPAR $\alpha$ deletion in mice showed impaired whole-body fatty acid homeostasis not only during fasting, but also when fed a methionine- and choline-deficient diet or HFD. This PPAR $\alpha$ deletion is sufficient in promoting steatosis and hence establishes PPAR $\alpha$ as a relevant drug target in NAFLD [110].

\section{2. $P P A R \beta / \delta$}

Hepatic PPAR $\beta / \delta$ expression was shown in rats [123,124], adult humans [125-127], and mice [128]. A high mRNA expression was described for rat hepatocytes, endothelial and Kupffer cells [109], as well as in HSCs [129]. The liver was identified as a major PPAR $\beta / \delta$-responsive organ, because a PPAR $\delta$ specific agonist suppressed hepatic glucose output and increased glucose disposal [130].

Due to its seemingly critical role in the liver, this pathway could contribute to the ability of PPAR $\beta / \delta$ agonists to alleviate hyperglycemia and improve insulin sensitivity [130].

PPAR $\beta / \delta$ has been shown to govern hepatic glucose utilization and lipoprotein metabolism and an anti-inflammatory role was previously supported [131]. In detail, the primary metabolic influence of PPAR in the liver was shown to act on the carbohydrate and lipoprotein metabolism, since $\operatorname{PPAR} \beta / \delta$ deletion lead to a downregulation of numerous pathways of the carbohydrate metabolism. These include the pentose-phosphate pathway, mannose and fructose metabolism, and in particular, glycolysis. Genes in the latter pathway, that were clearly decreased in PPAR $\beta / \delta^{-/-}$mice, included pyruvate kinase ( $P k l r)$ and fructose 1,6 bisphosphatase ( Fbp 1 ). In addition, PPAR $\beta / \delta$ deletion was associated with decreased expression of a number of genes connected with lipoprotein metabolism 
(Apoa4, Lipg), very low density lipoprotein receptor (Vldlr), and elevated plasma triglyceride levels in $\operatorname{PPAR} \beta / \delta^{-/-}$mice in the fed state [131].

PPAR $\delta$ activation was further shown to reduce fasting glucose levels in chow- and high-fat fed mice [132]. This effect was accompanied by hepatic glycogen and lipid deposition as well as up-regulation of glucose utilization and de novo lipogenesis pathways. It was therefore suggested, that PPAR $\beta / \delta$ controls the hepatic energy substrate homeostasis by coordinated regulation of glucose and fatty acid metabolism, which provides a molecular basis for developing PPAR $\delta$ agonists in order to manage hyperglycemia and insulin resistance [132].

\subsection{PPAR $\gamma$}

Two isoforms of PPAR $\gamma$ protein were described (PPAR $\gamma 1$ and PPAR $\gamma 2$ ) and gene products actually generated three mRNAs with the PPARy1 and 3 encoding PPAR $\gamma 1$ protein [61].

$\operatorname{PPAR} \gamma$ was found to be strongly expressed in adipose tissue, but human and murine liver contained lower levels $[133,134]$, and equally low transcript levels in rat liver [123]. Recent findings have revealed that in several murine models of obesity and type 2 diabetes mellitus, PPAR $\gamma$ mRNA and receptor proteins are highly up-regulated in the liver. The receptor caused increased transcriptional activity as was demonstrated by the activation of PPAR $\gamma$-responsive genes in the liver [135-137]. This was further supported by up-regulation of the hepatic PPAR $\gamma$ mRNA and protein expression in a diet-induced NAFLD murine model [138].

Treatment with troglitazone, an antidiabetic drug, and thiazolidinone which is targeted by PPAR $\gamma$, induced the expression of several PPAR $\gamma$-responsive genes, including aP2, fatty acid translocase (FAT)/CD36, and uncoupling protein-2 (UCP2) in the liver of $o b / o b$ mice. Thus, raising the possibility that the effects of PPAR $\gamma$ agonists on lipid metabolism and energy balance may partly be mediated through their effects in the liver [137]. PPAR $\gamma 2$ was proposed to act as an inducer of steatosis in hepatocytes, possibly through an induction of pathways regulating de novo lipid synthesis [139]. Accordingly, hepatospecific PPAR $\gamma$ deletion reduced hepatic fat content in mice fed a HFD that developed hepatic steatosis. This further suggests that PPAR $\gamma$ expression in the liver, especially in hepatocytes, can function as a steatogenic inducer gene [138]. In the human non-alcoholic fatty liver, PPAR $\gamma 2$ and corresponding genes involved in fatty acid partitioning and binding, lipolysis, and monocyte/macrophage recruitment and inflammation were up-regulated [140]. PPAR $\gamma$ was up-regulated in the liver of obese patients with NAFLD, which showed positive associations with SREBP-1c mRNA levels or serum insulin levels, reinforcing a lipogenic mechanism to SREBP-1c induction and up-regulating genes that encode for lipogenic proteins in the development of hepatic steatosis [141].

Elimination of PPAR $\gamma$ in the liver of lipoatrophic A-ZIP/F-1 (AZIP) mice had beneficial effects on the hepatic steatosis. However and not entirely favorable, PPAR $\gamma$ elimination also aggravated the pathological conditions of hyperlipidemia, triglyceride clearance, and muscle insulin resistance [142]. In AZIP-mice lacking a functioning liver PPAR $\gamma$, the hypoglycemic and hypolipidemic effects of rosiglitazone, an anti-diabetic drug, were abrogated, thereby determining the liver as the major site of action in the absence of adipose tissue. The same drug remained effective in wild-type mice lacking PPAR $\gamma$ in the liver. It could be concluded that adipose tissue is the main target site of thiazolidinediones under normal conditions [142]. Wild-type mice lacking the PPAR $\gamma$ gene in the liver exhibited a fat intolerance, increased adiposity and as a result of triglyceride imbalance, developed hyperlipidemia and insulin resistance. Ultimately, these factors led to hepatic steatosis. Liver PPAR $\gamma$ seems to protect other tissues from triglyceride accumulation and insulin resistance [142]. Liver-specific disruption of PPAR $\gamma$ in diabetic mice dramatically decreased hepatic triglyceride and systemically aggravated insulin resistance [143]. PPAR $\gamma$ regulated the expression of lipogenic genes independently from LXR $\alpha$ (nuclear hormone receptors liver $\mathrm{X}$ receptor $\alpha$ ) and therefore likely contributes to the generation of fatty liver [144]. Findings indicated that PPAR $\gamma 2$ directly increased hepatic de novo lipogenesis and hepatic triglyceride concentrations [145]. Further investigations have suggested that Cd36-mediated 
FA uptake and monoacylglycerol (MAG) pathway-mediated FA esterification are major targets of hepatocyte PPAR $\gamma$. Dysregulation of these FA signaling mechanisms could explain in part the protection against steatosis observed after liver (hepatocyte)-specific PPAR $\gamma$ knockdown (aLivPPAR $\gamma \mathrm{kd}$ ) [146]. ALivPPAR $\gamma k d$ dramatically reduced Mogat1 expression, which was reflected by an increase in hepatic MAG levels and indicated a reduced monoacylglycerol O-acyltransferase 1 (MOGAT) activity [146]. Another finding demonstrated that PPAR $\gamma$ orchestrated a gene-expression program downstream of the PI3K/Akt2 pathway, favoring aerobic glycolysis, lipogenesis, and pathophysiological growth. For PPAR $\gamma$, a cell-autonomous regulation of glycolytic isoenzymes hexokinase 2 and M2 isoform of pyruvate kinase was suggested [147].

Taking together, modulation of receptors related to the endocannabinoid system seems to have a strong impact on liver functions, preferentially by influencing the glycolysis and lipid metabolism (Figure 3).

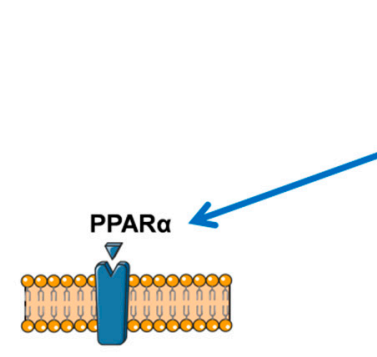

Agonism/stimulation TG accumulation $\downarrow$ FA uptake $\uparrow$ Lipoprotein synthesis $\uparrow$ FA oxidation $\uparrow$ Phospholipid remodeling $\uparrow$ IL-6 pathway $\downarrow$ Hepatic inflammation $\downarrow$ Antioxidant enzymes $\uparrow$ Hepatic fibrosis $\downarrow$ Ketone body synthesis $\uparrow$ Gluconeogenesis $\uparrow$ HSCs $\downarrow$

Antagonism/knockout Steatosis $\uparrow$ Oxidative stress $\uparrow$ Inflammation $\uparrow$

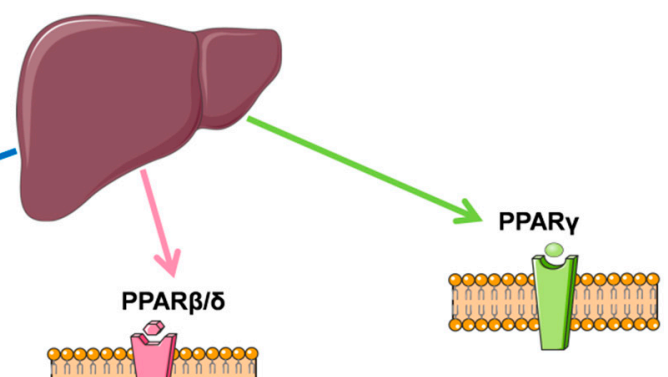

Agonism/stimulation Lipogenic gene regulation $\uparrow$ Hepatic de novo lipogenesis $\uparrow$ TG content $\uparrow$

\section{Glucose levels $\downarrow$} Hepatic glycogen and lipid deposition $\uparrow$ Glucose utilization $\uparrow$ De novo lipogenesis $\uparrow$

Antagonism/knockout Carbohydrate metabolism $\downarrow$ Glycolysis $\downarrow$ Lipoprotein metabolism $\downarrow$ Plasma TG levels $\uparrow$

Figure 3. Schematic illustration of peroxisome proliferation-activated receptor (PPAR) function in liver metabolism. $(\uparrow)$ and $(\downarrow)$ define up or down regulation. Most findings were generated in rodent models. This figure was prepared using a template on the Servier Medical Art website (Available at: http://smart.servier.com/).

\section{Endocannabinoid System and Liver Cirrhosis}

As shown above, the endocannabinoid system regulates a wide spectrum of the glucose and lipid metabolism in liver tissue and the impairment of this interaction results in various metabolic disturbances. Accumulation of fat and insulin resistance are the main causes of NAFLD. NAFLD can be classified in two separate entities: non-alcoholic fatty liver or steatosis and non-alcoholic steatohepatitis [148]. Steatosis is characterized by accumulation of fat in more than $5 \%$ of the hepatocytes. Inflammation and fibrotic tissue define the presence of NASH. In NASH, hepatocyte injury and damage causes inflammation with direct and indirect activation of immune cells. On the one hand these cells include resident macrophage in the liver, i.e., Kupffer cells and HSCs, and on the other hand infiltrating neutrophils, macrophages, T lymphocytes, and dendritic cells. All cells contribute to liver inflammation and production of proinflammatory cytokines and mediators $[148,149]$. This inflammation subsequently activates HSCs, which are the main cell type producing fibrotic tissue. Activation of HSCs leads to changes in the phenotype of these cells, developing into myofibroblast-like 
cells. As a consequence of these processes, fibrotic tissue accumulates in the liver with subsequent progression of NASH, leading to cirrhosis.

\subsection{Endocannabinoids $A E A, 2-A G$, and $P E A$}

Recently, it is widely accepted that the normal liver contains the endocannabinoids AEA and 2-AG. There are studies showing relatively low levels of AEA and 2-AG [150], although it is also reported that anandamide and 2-AG are present in the liver at levels similar to those in brain [151,152]. Several types of liver cells including hepatocytes, HSCs and vascular endothelial cells are able to produce the AEA and 2-AG under physiological conditions $[32,33,153]$. The differences in their levels might be a matter of fasting. Data obtained from different animals models of obesity revealed that DIO mice [25] and Zucker rats exhibited basal and food deprivation/refeeding-induced changes in endocannabinoid levels, e.g., significantly higher 2-AG and/or AEA levels in the liver [154].

There are several studies investigating the expression of endocannabinoids in liver diseases. For example, in acute hepatitis, serum anandamide levels were found to correlate with the extent of tissue damage [155]. Another study indicated that serum levels of endocannabinoids are significantly increased in patients with NAFLD, regardless of their body mass index (BMI), and could be correlated with several metabolic parameters and transaminases [156]. Increased serum concentrations of 2-AG and its precursor and breakdown molecule, arachidonic acid were detected, however, with no significant differences in serum AEA levels in both female and male patients with NAFLD [156].

However, peripheral AEA is increased in patients with end-stage liver disease and the upregulation of the endocannabinoid-related molecules, OEA and palmitoylethanolamine, were even greater than that of AEA [157]. In contrast, the 2-AG levels were not affected by cirrhosis. Interestingly, the major source of elevated endocannabinoids in plasma was extrahepatic presumably a general response to inflammatory processes during cirrhosis.

Both endocannabinoids AEA and 2-AG by themselves seem to have antifibrotic properties, partly independent of cannabinoid receptors. The main responsible liver cell type for producing fibrosis is the HSC, which physiologically constitutes about $5-8 \%$ of liver cells. Activation of stellate cells is one of the key mechanisms in the development of fibrosis and cirrhosis. When activated, HSCs change their phenotype to myofibroblast-like cells and undergo morphological and functional changes [158,159]. Remarkably enough, HSCs are also one of the main cells to reverse fibrosis and cirrhosis, which is a consequence of less proliferation and quiescence of the HSCs. In this context, AEA has been considered a potential antifibrogenic tool, since it efficiently induced necrosis in activated HSCs and inhibited the HSC proliferation as shown in surgical specimens of healthy human and rat livers [160]. Higher doses of 2-AG also induced apoptosis in activated HSCs through a receptor independent mechanism, suggesting 2-AG may act as an antifibrogenic mediator in the liver by inducing quiescence in HSCs $[161,162]$. These findings are further supported by in vitro data. Palmitoylethanolamide (PEA) as a natural occurring cannabinoid shows structurally a close similarity to anandamide. Functionally, it binds neither to $\mathrm{CB}_{1}$ nor $\mathrm{CB}_{2}$ nor abnormal cannabidiol sensitive receptor [163]. PEA in micromolar concentrations is a major activator of PPARs and suppresses the activation of immune cells such as it prevents the degranulation of mast cells, reduces leukocyte migration to extracellular space and inhibits the proinflammatory cytokine release from macrophages [164,165]. PEA seems to aggravate the effects of other endocannabinoids and in turn its effects are reduced after blocking the $\mathrm{CB}_{2}$ receptor $[166,167]$.

$\mathrm{N}$-arachidonoyl dopamine, another endocannabinoid, induced dose-dependent cell death in culture-activated primary murine or human HSCs [168]. However, the endogenous cannabinoids AEA and 2-AG are ubiquitous lipid signaling molecules, exhibiting effects that were mediated mostly by activation of both specific receptors $\mathrm{CB}_{1}$ and $\mathrm{CB}_{2}$ [36].

\section{2. $C B_{1}$ - and $C B_{2}$-Receptor}

Based on the low expression of the receptors the endocannabinoid system is quiescent in normal livers. The progression from an initial liver damage to fibrosis and subsequent cirrhosis is a highly 
complex process and involves all liver cell types. The role of the ESC in this complex process depends on the progress of the disease.

Endocannabinoids and their hepatic cannabinoid receptors are upregulated in NAFLD and in cirrhosis [162,169-171]. Interestingly, the action of $\mathrm{CB}_{1}$ and $\mathrm{CB}_{2}$ receptors are conversely related with decrease of fibrosis by $\mathrm{CB}_{1}$ deficiency and increased collagen deposition by $\mathrm{CB}_{2}$ deletion $[36,172]$.

$\mathrm{CB}_{1}$ receptors are upregulated in the liver of cirrhotic individuals and overexpressed in liver fibrogenic cells [32]. $\mathrm{CB}_{1}$ blockade or inactivation has been associated with decreased amounts of fibrosis, reduced expression of TGF- $\beta$ and decreased amounts of fibrogenic cells [36]. $\mathrm{CB}_{1}$-deficient mice exhibited reduced fibrosis after exposure to chronic carbon tetrachloride $\left(\mathrm{CCl}_{4}\right)$ [173]. Accordingly, chronic $\mathrm{CB}_{1}$ receptor blockade with $\mathrm{AM}-251$ in the hepatic microcirculation of common bile-duct-ligated cirrhotic rats was associated with decreased hepatic collagen deposition and an activated phospholipase $\mathrm{A}_{2}$ (PLA $\mathrm{PL}_{2}$ /eicosanoid cascade in the cirrhotic liver, mediated by the inhibition of hepatic TGF- $\beta_{1}$ activity [174]. The antifibrogenic potential of $\mathrm{CB}_{1}$ antagonism was also confirmed in $\mathrm{C57 \textrm {BL } / 6 \mathrm { J } \text { mice }}$ given a prolonged HFD to induce NASH and fibrosis [175]. In support of this, rats with $\mathrm{CCl}_{4}$-induced cirrhosis had reduced liver fibrosis after a 2-week treatment with $\mathrm{CB}_{1}$-antagonist rimonabant [176]. In conclusion, endocannabinoids and the $\mathrm{CB}_{1}$ receptor are involved in the development of fibrosis and cirrhosis. Subsequent regression of fibrosis can be achieved by the pharmacological blockade of $\mathrm{CB}_{1}$ receptor antagonism even in an advanced stage of the disease when cirrhosis has already developed [177]. This effect was associated with the suppression of a series of pro-fibrogenic and inflammatory mediators [177] and was shown in different animal models of fibrosis and cirrhosis, including NASH.

$\mathrm{CB}_{1}$ activation has also been implicated in liver regeneration in mice. This is due to the fact that $\mathrm{AEA}$, by acting via $\mathrm{CB}_{1}$, regulates the expression of key cell cycle proteins required for mitotic progression in the regenerating liver. Lack of $\mathrm{CB}_{1}$ or $\mathrm{CB}_{2}$ blockade by rimonabant was followed by a reduced liver regeneration [178].

$\mathrm{CB}_{2}$ receptors were shown to be highly up-regulated in the cirrhotic human liver, predominantly in hepatic fibrogenic cells [30]. In the same study, mice with impaired $\mathrm{CB}_{2}$ receptors developed enhanced liver fibrosis after $\mathrm{CCl}_{4}$ treatment. Accordingly, $\mathrm{CB}_{2}$ knockout mice had an enhanced response to fibrogenic stimuli [30]. The administration of the $\mathrm{CB}_{2}$ agonist JWH-133 in the $\mathrm{CCl}_{4}$ mouse model reduced the extent of liver injury, indicating that $\mathrm{CB}_{2}$ receptor activation alleviates $\mathrm{CCl}_{4}$-induced hepatitis and accelerates liver regeneration. Thereby, $\mathrm{CB}_{2}$ agonists have been identified as potential beneficial hepatoprotective agents, in addition to their antifibrogenic effects [179]. Accordingly, selective activation of hepatic $\mathrm{CB}_{2}$ receptors limited the progression of experimental liver fibrosis as shown in reduced hepatic collagen content in rats with pre-existing cirrhosis [180]. $\mathrm{CB}_{2}$ receptor stimulation prevented fibrosis progression in $\mathrm{CCl}_{4}$-treated rats and by that, displaying reduced hepatic collagen content, improved mean arterial pressure and portal pressure, ameliorated cell viability, and reduced angiogenesis and cell infiltration compared with untreated fibrotic rats [181]. Others demonstrated that $\mathrm{CB}_{2}$ receptor activation decreased liver fibrosis by selectively reducing interleukin 17 (IL-17) production of T-helper (Th)17 lymphocytes via a signal transducer and activator of transcription (STAT)5-dependent pathway, and by blunting the proinflammatory effects of IL-17 on its target cells, while preserving IL-22 production [182].

Taken together, rodent studies have indicated that $\mathrm{CB}_{2}$ agonism can reduce the progression of liver fibrosis by decreasing the inflammatory infiltrate (Figure 4).

Whereas, in $\mathrm{CB}_{2}$-antagonism or in $\mathrm{CB}_{2}{ }^{-1-}$ mice an increased collagen deposition, liver fat content, and enhanced inflammatory score was described. These data are further supported by human studies. Recently, a critical role for $\mathrm{CB}_{2}$ receptor signaling was confirmed in obese children with NAFLD by showing that the presence of the functional variant of the $\mathrm{CB}_{2}(\mathrm{Q} 63 \mathrm{R})$ correlates with severity of the liver inflammation and the presence of NASH [183]. 


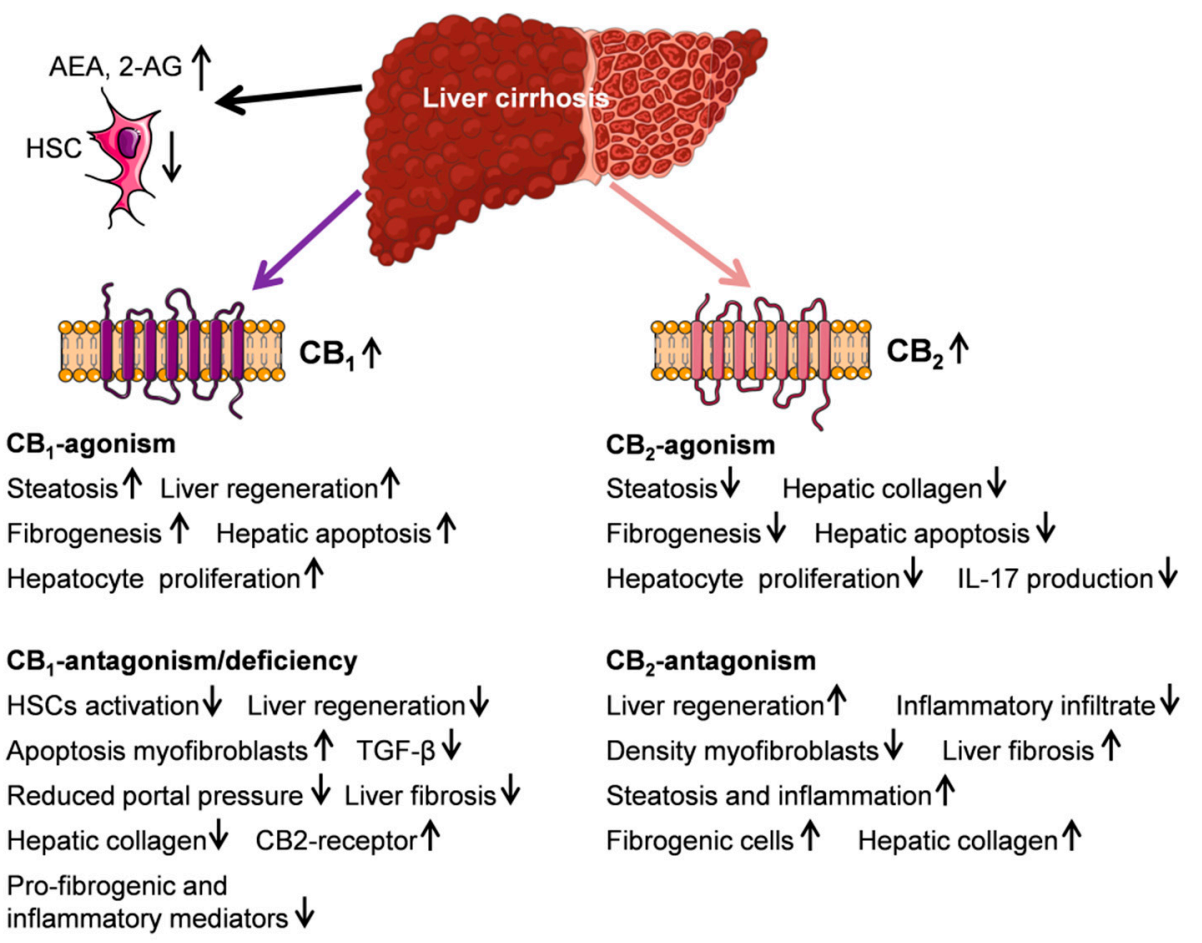

Figure 4. Schematic illustration of cannabinoid receptor (CBR) function in the metabolism of liver cirrhosis. $(\uparrow)$ and $(\downarrow)$ define up or down regulation. Most findings were generated in rodent models. This figure was prepared using a template on the Servier Medical Art website (Available at: http://smart.servier.com/).

\subsection{Endocannabinoids and Hemodynamics in Cirrhosis}

Cirrhosis is the end stage of different liver diseases and is defined by replacement of normal liver tissue by fibrotic tissue. Activated HSCs undergo myofibroblast-like transformation and mainly produce the fibrotic tissue $[184,185]$. Other morphologically and functionally different fibroblastic cells, i.e., liver myofibroblasts also contribute to the production of fibrotic tissue in the liver [186]. The damage of the hepatocytes and the increase of fibrotic tissue have different consequences in regard to liver function, liver anatomy, and increase of intrahepatic vascular resistance. The decrease of liver function is resulting in lower degradation and less production of substances. One of the most important substance with lower production in cirrhosis is albumin, which is not only less produced but also dysfunctional. The presence of dysfunctional albumin in cirrhosis explains the strong positive reaction of sodium elimination after exogenous albumin administration.

Another consequence of the increased fibrotic tissue and the destroyed anatomy is the increase of intrahepatic vascular resistance and subsequent development of portal pressure. Portal pressure is the main cause for the development of complications in cirrhotic patients such as the development of ascites and variceal hemorrhage [187]. Furthermore, portal hypertension also causes changes in the splanchnic and systemic vascular system. One of the mechanisms involved in the splanchnic vasodilation is an increase in bacterial translocation in the gut and increase of pathogen-associated molecular pattern release [188]. These activate innate pattern recognition receptors and release proinflammatory molecules, like reactive oxygen species and reactive nitrogen species. The release of proinflammatory molecules is one mechanism behind the decrease of the splanchnic vascular resistance. This splanchnic vasodilatation is one of the drivers of systemic vasodilatation and increased cardiac output. Splanchnic and systemic vasodilation lead to activation of different hormonal systems, mainly the renin-angiotensin-aldosterone system. This causes increased levels of angiotensin and aldosterone and leads to retention of sodium and water, which causes a vicious circle that worsens the development of ascites [188]. 
Based on several studies it is widely accepted that the concentration of nitric oxide (NO) is increased in the splanchnic and systemic circulation in cirrhosis [189]. A higher concentration of NO is caused by increased levels of endothelial nitric oxide synthethase (eNOS) [190]. The enhanced expression and increased activation of eNOS and augmented endothelial NO release in the vessels is mainly caused by a response to flow and shear stress. This increased eNOS-derived NO production could be explained as normal chronic adaptation of the endothelium in response to chronically elevated splanchnic blood flow in portal hypertension [189]. In cirrhotic rats, blockade of $\mathrm{CB}_{1}$ reversed the systemic hypotension, reduced the portal pressure and the mesenteric blood flow $[170,191]$. The mechanisms behind these processes are not completely understood. Studies indicated that both circulating inflammatory cells and endothelial receptors were involved. In fact, monocytes isolated from the blood of cirrhotic rats and patients, but not from normal controls, caused $\mathrm{CB}_{1}$-receptor-mediated hypotension when injected into normal rats. This seemed to be mediated by elevated levels of anandamide from cirrhotic monocytes and elevated levels of $\mathrm{CB}_{1}$ receptors from cirrhotic patients in hepatic vascular endothelial cells [170].

A likely source of endocannabinoids in cirrhosis could be activated macrophages, in which lipopolysaccharides induced the synthesis of AEA [192,193]. Indeed, AEA levels were elevated in circulating macrophages of cirrhotic rats and patients [192,193]. Together with the increased expression of $\mathrm{CB}_{1}$ receptors in mesenteric arteries, the vasodilatory property of increased levels of AEA was even higher [194-196]. These findings suggest AEA as a mediator of splanchnic vasodilation in cirrhosis in a NO independent manner [128].

High cardiac output and low systemic vascular resistance define the hyperdynamic circulation of advanced cirrhosis. Despite this high cardiac output, the cirrhotic cardiomyopathy is defined as a decrease in contractility [197]. There is evidence that the $C_{1}$ receptor was involved in the suppression of cardiac contractility and blockade of the $\mathrm{CB}_{1}$ receptor normalized the contractility $[198,199]$. Besides the suppression of cardiac contractility by $\mathrm{CB}_{1}$ receptor activation, increased myocardial levels of AEA in cirrhosis suggested a further involvement of this pathway in cirrhotic cardiomyopathy [199]. Taking together, endocannabinoids and their classical receptors $\mathrm{CB}_{1}$ and $\mathrm{CB}_{2}$ seem to be involved in the hemodynamic changes seen in cirrhosis.

\section{Summary and Conclusions}

Hepatic lipid and glucose metabolism was previously indicated as a potential target of the metabolic actions of the endocannabinoid system (ECS).

As further shown by different experimental animal and human studies, the pharmacological and genetic modulation of the ECS is able to induce metabolic changes, extracellular remodeling and the progression of fibrosis. These numerous effects state the importance of ECS in the pathophysiology of metabolic liver diseases such as steatosis and subsequent development of fibrosis.

Thus, the first selective $\mathrm{CB}_{1}$ receptor antagonist rimonabant was approved for the treatment of obesity. Unfortunately, it was expected to cause centrally mediated neuropsychiatric side effects, which resulted in the withdrawal of this substance from the market. Currently, further peripherally based agonists or antagonist are under investigation in preclinical settings. They aim at unraveling the pathophysiology of the ECS and to find suitable novel therapeutic tools for the treatment of liver diseases.

For this, however, a better identification of specific signaling pathways of each cannabinoid receptor is necessary, including their interactions within a hepatic cell. In addition, the cross-talk between different hepatic cell types and the understanding of their interactions is crucial to further elucidate the role of ECS in the pathogenesis of liver fibrosis and fatty liver disease.

Author Contributions: I.B.-W. and A.Z. wrote the manuscript. I.B.-W. designed the figures. F.D. supervised and edited the manuscript.

Funding: The publication was supported by the funding program Open Access Publishing by the German Research Foundation (DFG).

Acknowledgments: Authors thank Olivia Mühlbauer for helpful discussions and critical reading of the manuscript. 
Conflicts of Interest: The authors declare no conflict of interest.

\section{References}

1. Simon, V.; Cota, D. MECHANISMS IN ENDOCRINOLOGY: Endocannabinoids and metabolism: Past, present and future. Eur. J. Endocrinol. 2017, 176, R309-R324. [CrossRef] [PubMed]

2. de Petrocellis, L.; Cascio, M.G.; Di Marzo, V. The endocannabinoid system: A general view and latest additions. Br. J. Pharmacol. 2004, 141, 765-774. [CrossRef] [PubMed]

3. Howlett, A.C.; Breivogel, C.S.; Childers, S.R.; Deadwyler, S.A.; Hampson, R.E.; Porrino, L.J. Cannabinoid physiology and pharmacology: 30 years of progress. Neuropharmacology 2004, 47, 345-358. [CrossRef]

4. Di Marzo, V. CB(1) receptor antagonism: Biological basis for metabolic effects. Drug Discov. Today 2008, 13, 1026-1041. [CrossRef]

5. Pertwee, R.G.; Howlett, A.C.; Abood, M.E.; Alexander, S.P.H.; Di Marzo, V.; Elphick, M.R.; Greasley, P.J.; Hansen, H.S.; Kunos, G.; Mackie, K.; et al. International Union of Basic and Clinical Pharmacology. LXXIX. Cannabinoid receptors and their ligands: Beyond $\mathrm{CB}_{1}$ and $\mathrm{CB}_{2}$. Pharmacol. Rev. 2010, 62, 588-631. [CrossRef] [PubMed]

6. Piomelli, D. The molecular logic of endocannabinoid signalling. Nat. Rev. Neurosci. 2003, 4, 873-884. [CrossRef]

7. Demuth, D.G.; Molleman, A. Cannabinoid signalling. Life Sci. 2006, 78, 549-563. [CrossRef]

8. O'Sullivan, S.E. Cannabinoids go nuclear: Evidence for activation of peroxisome proliferator-activated receptors. Br. J. Pharmacol. 2007, 152, 576-582. [CrossRef]

9. Bouaboula, M.; Hilairet, S.; Marchand, J.; Fajas, L.; Le Fur, G.; Casellas, P. Anandamide induced PPARgamma transcriptional activation and 3T3-L1 preadipocyte differentiation. Eur. J. Pharmacol. 2005, 517, 174-181. [CrossRef]

10. Astarita, G.; Ahmed, F.; Piomelli, D. Identification of biosynthetic precursors for the endocannabinoid anandamide in the rat brain. J. Lipid Res. 2008, 49, 48-57. [CrossRef] [PubMed]

11. Kano, M.; Ohno-Shosaku, T.; Hashimotodani, Y.; Uchigashima, M.; Watanabe, M. Endocannabinoid-mediated control of synaptic transmission. Physiol. Rev. 2009, 89, 309-380. [CrossRef] [PubMed]

12. Jourdan, T.; Godlewski, G.; Kunos, G. Endocannabinoid regulation of $\beta$-cell functions: Implications for glycaemic control and diabetes. DiabetesObes. Metab. 2016, 18, 549-557. [CrossRef] [PubMed]

13. Matsuda, L.A.; Lolait, S.J.; Brownstein, M.J.; Young, A.C.; Bonner, T.I. Structure of a cannabinoid receptor and functional expression of the cloned cDNA. Nature 1990, 346, 561-564. [CrossRef] [PubMed]

14. Herkenham, M.; Lynn, A.B.; Little, M.D.; Johnson, M.R.; Melvin, L.S.; de Costa, B.R.; Rice, K.C. Cannabinoid receptor localization in brain. Proc. Natl. Acad. Sci. USA 1990, 87, 1932-1936. [CrossRef] [PubMed]

15. Munro, S.; Thomas, K.L.; Abu-Shaar, M. Molecular characterization of a peripheral receptor for cannabinoids. Nature 1993, 365, 61-65. [CrossRef]

16. Buckley, N.E.; McCoy, K.L.; Mezey, E.; Bonner, T.; Zimmer, A.; Felder, C.C.; Glass, M. Immunomodulation by cannabinoids is absent in mice deficient for the cannabinoid $\mathrm{CB}(2)$ receptor. Eur. J. Pharmacol. 2000, 396, 141-149. [CrossRef]

17. Morales, P.; Reggio, P.H. An Update on Non-CB1, Non-CB2 Cannabinoid Related G-Protein-Coupled Receptors. Cannabis Cannabinoid Res. 2017, 2, 265-273. [CrossRef]

18. Herkenham, M.; Lynn, A.B.; Johnson, M.R.; Melvin, L.S.; de Costa, B.R.; Rice, K.C. Characterization and localization of cannabinoid receptors in rat brain: A quantitative in vitro autoradiographic study. J. Neurosci. 1991, 11, 563-583. [CrossRef]

19. Devane, W.A.; Hanus, L.; Breuer, A.; Pertwee, R.G.; Stevenson, L.A.; Griffin, G.; Gibson, D.; Mandelbaum, A.; Etinger, A.; Mechoulam, R. Isolation and structure of a brain constituent that binds to the cannabinoid receptor. Science 1992, 258, 1946-1949. [CrossRef]

20. Dalton, G.D.; Bass, C.E.; van Horn, C.G.; Howlett, A.C. Signal transduction via cannabinoid receptors. CNS Neurol. Disord. Drug Targets 2009, 8, 422-431. [CrossRef]

21. van Sickle, M.D. Identification and functional characterization of brainstem cannabinoid CB2 receptors. Science 2005, 310, 329-332. [CrossRef] 
22. Skaper, S.D.; Buriani, A.; Dal Toso, R.; Petrelli, L.; Romanello, S.; Facci, L.; Leon, A. The ALIAmide palmitoylethanolamide and cannabinoids, but not anandamide, are protective in a delayed postglutamate paradigm of excitotoxic death in cerebellar granule neurons. Proc. Natl. Acad. Sci. USA 1996, 93, 3984-3989. [CrossRef]

23. Núñez, E.; Benito, C.; Pazos, M.R.; Barbachano, A.; Fajardo, O.; González, S.; Tolón, R.M.; Romero, J. Cannabinoid CB2 receptors are expressed by perivascular microglial cells in the human brain: An immunohistochemical study. Synapse 2004, 53, 208-213. [CrossRef]

24. Massa, F.; Storr, M.; Lutz, B. The endocannabinoid system in the physiology and pathophysiology of the gastrointestinal tract. J. Mol. Med. 2005, 83, 944-954. [CrossRef]

25. Osei-Hyiaman, D.; DePetrillo, M.; Pacher, P.; Liu, J.; Radaeva, S.; Bákai, S.; Harvey-White, J.; Mackie, K.; Offertáler, L.; Wang, L.; et al. Endocannabinoid activation at hepatic CB1 receptors stimulates fatty acid synthesis and contributes to diet-induced obesity. J. Clin. Investig. 2005, 115, 1298-1305. [CrossRef]

26. Cota, D.; Genghini, S.; Pasquali, R.; Pagotto, U. Antagonizing the cannabinoid receptor type 1: A dual way to fight obesity. J. Endocrinol. Investig. 2003, 26, 1041-1044. [CrossRef]

27. Tharp, W.G.; Lee, Y.-H.; Maple, R.L.; Pratley, R.E. The cannabinoid CB1 receptor is expressed in pancreatic delta-cells. Biochem. Biophys. Res. Commun. 2008, 372, 595-600. [CrossRef]

28. O'Keefe, L.; Simcocks, A.C.; Hryciw, D.H.; Mathai, M.L.; McAinch, A.J. The cannabinoid receptor 1 and its role in influencing peripheral metabolism. Diabetes Obes. Metab. 2014, 16, 294-304. [CrossRef]

29. Brown, S.M.; Wager-Miller, J.; Mackie, K. Cloning and molecular characterization of the rat CB2 cannabinoid receptor. Biochim. Biophys. Acta 2002, 1576, 255-264. [CrossRef]

30. Julien, B.; Grenard, P.; Teixeira-Clerc, F.; van Nhieu, J.T.; Li, L.; Karsak, M.; Zimmer, A.; Mallat, A.; Lotersztajn, S. Antifibrogenic role of the cannabinoid receptor CB2 in the liver. Gastroenterology 2005, 128, 742-755. [CrossRef]

31. Mendez-Sanchez, N.; Zamora-Valdes, D.; Pichardo-Bahena, R.; Barredo-Prieto, B.; Ponciano-Rodriguez, G.; Bermejo-Martínez, L.; Chavez-Tapia, N.C.; Baptista-González, H.A.; Uribe, M. Endocannabinoid receptor CB2 in nonalcoholic fatty liver disease. Liver Int. 2007, 27, 215-219. [CrossRef] [PubMed]

32. Teixeira-Clerc, F.; Julien, B.; Grenard, P.; van Tran Nhieu, J.; Deveaux, V.; Li, L.; Serriere-Lanneau, V.; Ledent, C.; Mallat, A.; Lotersztajn, S. CB1 cannabinoid receptor antagonism: A new strategy for the treatment of liver fibrosis. Nat. Med. 2006, 12, 671-676. [CrossRef] [PubMed]

33. Buckley, N.E.; Hansson, S.; Harta, G.; Mezey, E. Expression of the CB1 and CB2 receptor messenger RNAs during embryonic development in the rat. Neuroscience 1998, 82, 1131-1149. [CrossRef]

34. Auguet, T.; Berlanga, A.; Guiu-Jurado, E.; Terra, X.; Martinez, S.; Aguilar, C.; Filiu, E.; Alibalic, A.; Sabench, F.; Hernández, M.; et al. Endocannabinoid receptors gene expression in morbidly obese women with nonalcoholic fatty liver disease. BioMed Res. Int. 2014, 2014, 502542. [CrossRef] [PubMed]

35. Maccarrone, M.; Bab, I.; Bíró, T.; Cabral, G.A.; Dey, S.K.; Di Marzo, V.; Konje, J.C.; Kunos, G.; Mechoulam, R.; Pacher, P.; et al. Endocannabinoid signaling at the periphery: 50 years after THC. Trends Pharmacol. Sci. 2015, 36, 277-296. [CrossRef]

36. Mallat, A.; Teixeira-Clerc, F.; Deveaux, V.; Manin, S.; Lotersztajn, S. The endocannabinoid system as a key mediator during liver diseases: New insights and therapeutic openings. Br. J. Pharmacol. 2011, 163, 1432-1440. [CrossRef] [PubMed]

37. Mallat, A.; Teixeira-Clerc, F.; Lotersztajn, S. Cannabinoid signaling and liver therapeutics. J. Hepatol. 2013, 59, 891-896. [CrossRef]

38. Alswat, K.A. The role of endocannabinoids system in fatty liver disease and therapeutic potentials. Saudi J. Gastroenterol. 2013, 19, 144-151. [CrossRef]

39. Deveaux, V.; Cadoudal, T.; Ichigotani, Y.; Teixeira-Clerc, F.; Louvet, A.; Manin, S.; Nhieu, J.T.-V.; Belot, M.P.; Zimmer, A.; Even, P.; et al. Cannabinoid CB2 receptor potentiates obesity-associated inflammation, insulin resistance and hepatic steatosis. PLoS ONE 2009, 4, e5844. [CrossRef]

40. González-Mariscal, I.; Krzysik-Walker, S.M.; Doyle, M.E.; Liu, Q.-R.; Cimbro, R.; Santa-Cruz Calvo, S.; Ghosh, S.; Cieśla, Ł.; Moaddel, R.; Carlson, O.D.; et al. Human CB1 Receptor Isoforms, present in Hepatocytes and $\beta$-cells, are Involved in Regulating Metabolism. Sci. Rep. 2016, 6, 33302.

41. Godlewski, G.; Kunos, G. Overview of Nonclassical Cannabinoid Receptors. In The Receptors; Abood, M., Sorensen, R., Stella, N., Eds.; Springer: New York, NY, USA, 2013; Volume 24. 
42. Nie, J.; Lewis, D.L. The proximal and distal C-terminal tail domains of the CB1 cannabinoid receptor mediate G protein coupling. Neuroscience 2001, 107, 161-167. [CrossRef]

43. Nie, J.; Lewis, D.L. Structural domains of the CB1 cannabinoid receptor that contribute to constitutive activity and G-protein sequestration. J. Neurosci. 2001, 21, 8758-8764. [CrossRef]

44. Stadel, R.; Ahn, K.H.; Kendall, D.A. The cannabinoid type-1 receptor carboxyl-terminus, more than just a tail. J. Neurochem. 2011, 117, 1-18. [CrossRef]

45. Bazwinsky-Wutschke, I.; Zipprich, A.; Dehghani, F. Daytime-Dependent Changes of Cannabinoid Receptor Type 1 and Type 2 Expression in Rat Liver. Int. J. Mol. Sci. 2017, 18, 1844. [CrossRef]

46. Vollmers, C.; Gill, S.; DiTacchio, L.; Pulivarthy, S.R.; Le, H.D.; Panda, S. Time of feeding and the intrinsic circadian clock drive rhythms in hepatic gene expression. Proc. Natl. Acad. Sci. USA 2009, 106, 21453-21458. [CrossRef]

47. Chanda, D.; Kim, D.-K.; Li, T.; Kim, Y.-H.; Koo, S.-H.; Lee, C.-H.; Chiang, J.Y.L.; Choi, H.-S. Cannabinoid receptor type 1 (CB1R) signaling regulates hepatic gluconeogenesis via induction of endoplasmic reticulum-bound transcription factor cAMP-responsive element-binding protein $\mathrm{H}(\mathrm{CREBH})$ in primary hepatocytes. J. Biol. Chem. 2011, 286, 27971-27979. [CrossRef]

48. Zheng, Z.; Kim, H.; Qiu, Y.; Chen, X.; Mendez, R.; Dandekar, A.; Zhang, X.; Zhang, C.; Liu, A.C.; Yin, L.; et al. CREBH Couples Circadian Clock With Hepatic Lipid Metabolism. Diabetes 2016, 65, 3369-3383. [CrossRef]

49. Chanda, D.; Kim, Y.-H.; Kim, D.-K.; Lee, M.-W.; Lee, S.-Y.; Park, T.-S.; Koo, S.-H.; Lee, C.-H.; Choi, H.-S. Activation of cannabinoid receptor type $1(\mathrm{Cb} 1 \mathrm{r})$ disrupts hepatic insulin receptor signaling via cyclic AMP-response element-binding protein $\mathrm{H}$ (Crebh)-mediated induction of Lipin1 gene. J. Biol. Chem. 2012, 287, 38041-38049. [CrossRef]

50. Lamia, K.A.; Storch, K.-F.; Weitz, C.J. Physiological significance of a peripheral tissue circadian clock. Proc. Natl. Acad. Sci. USA 2008, 105, 15172-15177. [CrossRef]

51. Fukuda, H.; Iritani, N. Diurnal variations of lipogenic enzyme mRNA quantities in rat liver. Biochim. Biophys. Acta 1991, 1086, 261-264. [CrossRef]

52. Zardoya, R.; Diez, A.; Serradilla, M.C.; Madrid, J.A.; Bautista, J.M.; Garrido-Pertierra, A. Lipogenic activities in rat liver are subjected to circadian rhythms. Rev. Esp. De Fisiol. 1994, 50, 239-244.

53. Kunos, G. Understanding metabolic homeostasis and imbalance: What is the role of the endocannabinoid system? Am. J. Med. 2007, 120, S18-S24. [CrossRef] [PubMed]

54. Liu, J.; Cinar, R.; Xiong, K.; Godlewski, G.; Jourdan, T.; Lin, Y.; Ntambi, J.M.; Kunos, G. Monounsaturated fatty acids generated via stearoyl CoA desaturase- 1 are endogenous inhibitors of fatty acid amide hydrolase. Proc. Natl. Acad. Sci. USA 2013, 110, 18832-18837. [CrossRef] [PubMed]

55. Murdolo, G.; Kempf, K.; Hammarstedt, A.; Herder, C.; Smith, U.; Jansson, P.-A. Insulin differentially modulates the peripheral endocannabinoid system in human subcutaneous abdominal adipose tissue from lean and obese individuals. J. Endocrinol. Investig. 2007, 30, RC17-RC21. [CrossRef] [PubMed]

56. Ravinet Trillou, C.; Arnone, M.; Delgorge, C.; Gonalons, N.; Keane, P.; Maffrand, J.-P.; Soubrie, P. Anti-obesity effect of SR141716, a CB1 receptor antagonist, in diet-induced obese mice. Am. J. Physiol. Regul. Integr. Comp. Physiol. 2003, 284, R345-R353. [CrossRef]

57. Cinar, R.; Godlewski, G.; Liu, J.; Tam, J.; Jourdan, T.; Mukhopadhyay, B.; Harvey-White, J.; Kunos, G. Hepatic cannabinoid-1 receptors mediate diet-induced insulin resistance by increasing de novo synthesis of long-chain ceramides. Hepatology 2014, 59, 143-153. [CrossRef] [PubMed]

58. Jourdan, T.; Demizieux, L.; Gresti, J.; Djaouti, L.; Gaba, L.; Vergès, B.; Degrace, P. Antagonism of peripheral hepatic cannabinoid receptor-1 improves liver lipid metabolism in mice: Evidence from cultured explants. Hepatology 2012, 55, 790-799. [CrossRef]

59. Nogueiras, R.; Veyrat-Durebex, C.; Suchanek, P.M.; Klein, M.; Tschöp, J.; Caldwell, C.; Woods, S.C.; Wittmann, G.; Watanabe, M.; Liposits, Z.; et al. Peripheral, but not central, CB1 antagonism provides food intake-independent metabolic benefits in diet-induced obese rats. Diabetes 2008, 57, 2977-2991. [CrossRef]

60. de Gottardi, A.; Spahr, L.; Ravier-Dall'Antonia, F.; Hadengue, A. Cannabinoid receptor 1 and 2 agonists increase lipid accumulation in hepatocytes. Liver Int. 2010, 30, 1482-1489. [CrossRef]

61. Chen, J.; Montagner, A.; Tan, N.S.; Wahli, W. Insights into the Role of PPAR $\beta / \delta$ in NAFLD. Int. J. Mol. Sci. 2018, 19, 1893. [CrossRef] 
62. Wu, H.M.; Yang, Y.M.; Kim, S.G. Rimonabant, a cannabinoid receptor type 1 inverse agonist, inhibits hepatocyte lipogenesis by activating liver kinase B1 and AMP-activated protein kinase axis downstream of G $\alpha$ i/o inhibition. Mol. Pharmacol. 2011, 80, 859-869. [CrossRef]

63. Tam, J.; Vemuri, V.K.; Liu, J.; Bátkai, S.; Mukhopadhyay, B.; Godlewski, G.; Osei-Hyiaman, D.; Ohnuma, S.; Ambudkar, S.V.; Pickel, J.; et al. Peripheral CB1 cannabinoid receptor blockade improves cardiometabolic risk in mouse models of obesity. J. Clin. Investig. 2010, 120, 2953-2966. [CrossRef]

64. Tam, J.; Cinar, R.; Liu, J.; Godlewski, G.; Wesley, D.; Jourdan, T.; Szanda, G.; Mukhopadhyay, B.; Chedester, L.; Liow, J.-S.; et al. Peripheral cannabinoid-1 receptor inverse agonism reduces obesity by reversing leptin resistance. Cell Metab. 2012, 16, 167-179. [CrossRef] [PubMed]

65. Gary-Bobo, M.; Elachouri, G.; Gallas, J.F.; Janiak, P.; Marini, P.; Ravinet-Trillou, C.; Chabbert, M.; Cruccioli, N.; Pfersdorff, C.; Roque, C.; et al. Rimonabant reduces obesity-associated hepatic steatosis and features of metabolic syndrome in obese Zucker fa/fa rats. Hepatology 2007, 46, 122-129. [CrossRef]

66. Jourdan, T.; Djaouti, L.; Demizieux, L.; Gresti, J.; Vergès, B.; Degrace, P. CB1 antagonism exerts specific molecular effects on visceral and subcutaneous fat and reverses liver steatosis in diet-induced obese mice. Diabetes 2010, 59, 926-934. [CrossRef] [PubMed]

67. Liu, J.; Zhou, L.; Xiong, K.; Godlewski, G.; Mukhopadhyay, B.; Tam, J.; Yin, S.; Gao, P.; Shan, X.; Pickel, J.; et al. Hepatic cannabinoid receptor-1 mediates diet-induced insulin resistance via inhibition of insulin signaling and clearance in mice. Gastroenterology 2012, 142, 1218-1228. [CrossRef]

68. Ruby, M.A.; Nomura, D.K.; Hudak, C.S.S.; Mangravite, L.M.; Chiu, S.; Casida, J.E.; Krauss, R.M. Overactive endocannabinoid signaling impairs apolipoprotein E-mediated clearance of triglyceride-rich lipoproteins. Proc. Natl. Acad. Sci. USA 2008, 105, 14561-14566. [CrossRef] [PubMed]

69. Osei-Hyiaman, D.; Liu, J.; Zhou, L.; Godlewski, G.; Harvey-White, J.; Jeong, W.-I.; Bátkai, S.; Marsicano, G.; Lutz, B.; Buettner, C.; et al. Hepatic CB1 receptor is required for development of diet-induced steatosis, dyslipidemia, and insulin and leptin resistance in mice. J. Clin. Investig. 2008, 118, 3160-3169. [CrossRef]

70. Lipina, C.; Vaanholt, L.M.; Davidova, A.; Mitchell, S.E.; Storey-Gordon, E.; Hambly, C.; Irving, A.J.; Speakman, J.R.; Hundal, H.S. CB1 receptor blockade counters age-induced insulin resistance and metabolic dysfunction. Aging Cell 2016, 15, 325-335. [CrossRef] [PubMed]

71. Agudo, J.; Martin, M.; Roca, C.; Molas, M.; Bura, A.S.; Zimmer, A.; Bosch, F.; Maldonado, R. Deficiency of CB2 cannabinoid receptor in mice improves insulin sensitivity but increases food intake and obesity with age. Diabetologia 2010, 53, 2629-2640. [CrossRef] [PubMed]

72. Luyckx, F.H.; Lefebvre, P.J.; Scheen, A.J. Non-alcoholic steatohepatitis: Association with obesity and insulin resistance, and influence of weight loss. Diabetes Metab. 2000, 26, 98-106.

73. Yki-Järvinen, H. Fat in the liver and insulin resistance. Ann. Med. 2005, 37, 347-356. [CrossRef] [PubMed]

74. Chorvat, R.J. Peripherally restricted CB1 receptor blockers. Bioorganic Med. Chem. Lett. 2013, 23, 4751-4760. [CrossRef]

75. Banasch, M.; Goetze, O.; Schmidt, W.E.; Meier, J.J. Rimonabant as a novel therapeutic option for nonalcoholic steatohepatitis. Liver Int. 2007, 27, 1152-1155. [CrossRef] [PubMed]

76. Scheen, A.J.; Paquot, N. Inhibitors of cannabinoid receptors and glucose metabolism. Curr. Opin. Clin. Nutr. Metab. Care 2008, 11, 505-511. [CrossRef]

77. Kargl, J.; Balenga, N.; Parzmair, G.P.; Brown, A.J.; Heinemann, A.; Waldhoer, M. The cannabinoid receptor CB1 modulates the signaling properties of the lysophosphatidylinositol receptor GPR55. J. Biol. Chem. 2012, 287, 44234-44248. [CrossRef] [PubMed]

78. Pertwee, R.G. GPR55: A new member of the cannabinoid receptor clan? Br. J. Pharmacol. 2007, 152, 984-986. [CrossRef]

79. Ryberg, E.; Larsson, N.; Sjögren, S.; Hjorth, S.; Hermansson, N.-O.; Leonova, J.; Elebring, T.; Nilsson, K.; Drmota, T.; Greasley, P.J. The orphan receptor GPR55 is a novel cannabinoid receptor. Br. J. Pharmacol. 2007, 152, 1092-1101. [CrossRef]

80. Lauckner, J.E.; Jensen, J.B.; Chen, H.-Y.; Lu, H.-C.; Hille, B.; Mackie, K. GPR55 is a cannabinoid receptor that increases intracellular calcium and inhibits M current. Proc. Natl. Acad. Sci. USA 2008, 105, 2699-2704. [CrossRef]

81. Moriconi, A.; Cerbara, I.; Maccarrone, M.; Topai, A. GPR55: Current knowledge and future perspectives of a purported "Type-3" cannabinoid receptor. Curr. Med. Chem. 2010, 17, 1411-1429. [CrossRef] 
82. Petitet, F.; Donlan, M.; Michel, A. GPR55 as a new cannabinoid receptor: Still a long way to prove it. Chem. Biol. Drug Des. 2006, 67, 252-253. [CrossRef] [PubMed]

83. Sharir, H.; Abood, M.E. Pharmacological characterization of GPR55, a putative cannabinoid receptor. Pharmacol. Ther. 2010, 126, 301-313. [CrossRef]

84. Sawzdargo, M.; Nguyen, T.; Lee, D.K.; Lynch, K.R.; Cheng, R.; Heng, H.H.; George, S.R.; O’Dowd, B.F. Identification and cloning of three novel human $\mathrm{G}$ protein-coupled receptor genes GPR52, PsiGPR53 and GPR55: GPR55 is extensively expressed in human brain. Brain Res. Mol. Brain Res. 1999, 64, 193-198. [CrossRef]

85. Moreno-Navarrete, J.M.; Catalán, V.; Whyte, L.; Díaz-Arteaga, A.; Vázquez-Martínez, R.; Rotellar, F.; Guzmá, R.; Gómez-Ambrosi, J.; Pulido, M.R.; Russell, W.R.; et al. The L- $\alpha$-lysophosphatidylinositol/GPR55 system and its potential role in human obesity. Diabetes 2012, 61, 281-291. [CrossRef] [PubMed]

86. Simcocks, A.C.; O'Keefe, L.; Jenkin, K.A.; Mathai, M.L.; Hryciw, D.H.; McAinch, A.J. A potential role for GPR55 in the regulation of energy homeostasis. Drug Discov. Today 2014, 19, 1145-1151. [CrossRef]

87. Oka, S.; Toshida, T.; Maruyama, K.; Nakajima, K.; Yamashita, A.; Sugiura, T. 2-Arachidonoyl-sn-glycero-3phosphoinositol: A possible natural ligand for GPR55. J. Biochem. 2009, 145, 13-20. [CrossRef] [PubMed]

88. Masquelier, J.; Muccioli, G.G. Development and validation of a specific and sensitive HPLC-ESI-MS method for quantification of lysophosphatidylinositols and evaluation of their levels in mice tissues. J. Pharm. Biomed. Anal. 2016, 126, 132-140. [CrossRef]

89. Lipina, C.; Walsh, S.K.; Mitchell, S.E.; Speakman, J.R.; Wainwright, C.L.; Hundal, H.S. GPR55 deficiency is associated with increased adiposity and impaired insulin signaling in peripheral metabolic tissues. FASEB J. 2018, 33, 1299-1312. [CrossRef]

90. Díaz-Arteaga, A.; Vázquez, M.J.; Vazquez-Martínez, R.; Pulido, M.R.; Suarez, J.; Velásquez, D.A.; López, M.; Ross, R.A.; de Fonseca, F.R.; Bermudez-Silva, F.J.; et al. The atypical cannabinoid O-1602 stimulates food intake and adiposity in rats. Diabetes Obes. Metab. 2012, 14, 234-243.

91. Balenga, N.A.B.; Aflaki, E.; Kargl, J.; Platzer, W.; Schröder, R.; Blättermann, S.; Kostenis, E.; Brown, A.J.; Heinemann, A.; Waldhoer, M. GPR55 regulates cannabinoid 2 receptor-mediated responses in human neutrophils. Cell Res. 2011, 21, 1452-1469. [CrossRef]

92. Shore, D.M.; Reggio, P.H. The therapeutic potential of orphan GPCRs, GPR35 and GPR55. Front. Pharmacol. 2015, 6, 69. [CrossRef]

93. Ning, Y.; O'Neill, K.; Lan, H.; Pang, L.; Shan, L.X.; Hawes, B.E.; Hedrick, J.A. Endogenous and synthetic agonists of GPR119 differ in signalling pathways and their effects on insulin secretion in MIN6c4 insulinoma cells. Br. J. Pharmacol. 2008, 155, 1056-1065. [CrossRef]

94. Moran, B.M.; Flatt, P.R.; McKillop, A.M. G protein-coupled receptors: Signalling and regulation by lipid agonists for improved glucose homoeostasis. Acta Diabetol. 2016, 53, 177-188. [CrossRef]

95. Yang, J.W.; Kim, H.S.; Im, J.H.; Kim, J.W.; Jun, D.W.; Lim, S.C.; Lee, K.; Choi, J.M.; Kim, S.K.; Kang, K.W. GPR119: A promising target for nonalcoholic fatty liver disease. FASEB J. 2016, 30, 324-335. [CrossRef]

96. Yang, J.W.; Kim, H.S.; Choi, Y.-W.; Kim, Y.-M.; Kang, K.W. Therapeutic application of GPR119 ligands in metabolic disorders. Diabetes Obes. Metab. 2018, 20, 257-269. [CrossRef]

97. Bahirat, U.A.; Shenoy, R.R.; Goel, R.N.; Nemmani, K.V.S. APD668, a G protein-coupled receptor 119 agonist improves fat tolerance and attenuates fatty liver in high-trans fat diet induced steatohepatitis model in C57BL/6 mice. Eur. J. Pharmacol. 2017, 801, 35-45. [CrossRef]

98. Bahirat, U.A.; Shenoy, R.R.; Talwar, R.; Goel, R.N.; Nemmani, K.V.S. Co-administration of APD668, a G protein-coupled receptor 119 agonist and linagliptin, a DPPIV inhibitor, prevents progression of steatohepatitis in mice fed on a high trans-fat diet. Biochem. Biophys. Res. Commun. 2018, 495, 1608-1613. [CrossRef] [PubMed]

99. Mandard, S.; Müller, M.; Kersten, S. Peroxisome proliferator-activated receptor alpha target genes. Cell. Mol. Life Sci. 2004, 61, 393-416. [CrossRef] [PubMed]

100. Pistis, M.; Melis, M. From surface to nuclear receptors: The endocannabinoid family extends its assets. Curr. Med. Chem. 2010, 17, 1450-1467. [CrossRef]

101. O'Sullivan, S.E. An update on PPAR activation by cannabinoids. Br. J. Pharmacol. 2016, 173, 1899-1910. [CrossRef] [PubMed]

102. Kersten, S.; Desvergne, B.; Wahli, W. Roles of PPARs in health and disease. Nature 2000, 405, 421-424. [CrossRef] [PubMed] 
103. Wahli, W.; Michalik, L. PPARs at the crossroads of lipid signaling and inflammation. Trends Endocrinol. Metab. 2012, 23, 351-363. [CrossRef]

104. Zardi, E.M.; Navarini, L.; Sambataro, G.; Piccinni, P.; Sambataro, F.M.; Spina, C.; Dobrina, A. Hepatic PPARs: Their role in liver physiology, fibrosis and treatment. Curr. Med. Chem. 2013, 20, 3370-3396. [CrossRef] [PubMed]

105. Charbonnel, B. PPAR-alpha and PPAR-gamma agonists for type 2 diabetes. Lancet 2009, 374, 96-98. [CrossRef]

106. Lefebvre, P.; Chinetti, G.; Fruchart, J.-C.; Staels, B. Sorting out the roles of PPAR alpha in energy metabolism and vascular homeostasis. J. Clin. Investig. 2006, 116, 571-580. [CrossRef]

107. Tailleux, A.; Wouters, K.; Staels, B. Roles of PPARs in NAFLD: Potential therapeutic targets. Biochim. Biophys. Acta 2012, 1821, 809-818. [CrossRef]

108. Peters, J.M.; Rusyn, I.; Rose, M.L.; Gonzalez, F.J.; Thurman, R.G. Peroxisome proliferator-activated receptor alpha is restricted to hepatic parenchymal cells, not Kupffer cells: Implications for the mechanism of action of peroxisome proliferators in hepatocarcinogenesis. Carcinogenesis 2000, 21, 823-826. [CrossRef]

109. Hoekstra, M.; Kruijt, J.K.; van Eck, M.; van Berkel, T.J.C. Specific gene expression of ATP-binding cassette transporters and nuclear hormone receptors in rat liver parenchymal, endothelial, and Kupffer cells. J. Biol. Chem. 2003, 278, 25448-25453. [CrossRef]

110. Montagner, A.; Polizzi, A.; Fouché, E.; Ducheix, S.; Lippi, Y.; Lasserre, F.; Barquissau, V.; Régnier, M.; Lukowicz, C.; Benhamed, F.; et al. Liver PPAR $\alpha$ is crucial for whole-body fatty acid homeostasis and is protective against NAFLD. Gut 2016, 65, 1202-1214. [CrossRef]

111. Régnier, M.; Polizzi, A.; Lippi, Y.; Fouché, E.; Michel, G.; Lukowicz, C.; Smati, S.; Marrot, A.; Lasserre, F.; Naylies, C.; et al. Insights into the role of hepatocyte PPAR $\alpha$ activity in response to fasting. Mol. Cell. Endocrinol. 2018, 471, 75-88.

112. Devchand, P.R.; Keller, H.; Peters, J.M.; Vazquez, M.; Gonzalez, F.J.; Wahli, W. The PPARalpha-leukotriene B4 pathway to inflammation control. Nature 1996, 384, 39-43. [CrossRef]

113. Gervois, P.; Kleemann, R.; Pilon, A.; Percevault, F.; Koenig, W.; Staels, B.; Kooistra, T. Global suppression of IL-6-induced acute phase response gene expression after chronic in vivo treatment with the peroxisome proliferator-activated receptor-alpha activator fenofibrate. J. Biol. Chem. 2004, 279, 16154-16160. [CrossRef]

114. Toyama, T.; Nakamura, H.; Harano, Y.; Yamauchi, N.; Morita, A.; Kirishima, T.; Minami, M.; Itoh, Y.; Okanoue, T. PPARalpha ligands activate antioxidant enzymes and suppress hepatic fibrosis in rats. Biochem. Biophys. Res. Commun. 2004, 324, 697-704. [CrossRef]

115. Pawlak, M.; Lefebvre, P.; Staels, B. Molecular mechanism of PPAR $\alpha$ action and its impact on lipid metabolism, inflammation and fibrosis in non-alcoholic fatty liver disease. J. Hepatol. 2015, 62, 720-733. [CrossRef]

116. Fu, J.; Oveisi, F.; Gaetani, S.; Lin, E.; Piomelli, D. Oleoylethanolamide, an endogenous PPAR-alpha agonist, lowers body weight and hyperlipidemia in obese rats. Neuropharmacology 2005, 48, 1147-1153. [CrossRef]

117. Chen, L.; Li, L.; Chen, J.; Li, L.; Zheng, Z.; Ren, J.; Qiu, Y. Oleoylethanolamide, an endogenous PPAR- $\alpha$ ligand, attenuates liver fibrosis targeting hepatic stellate cells. Oncotarget 2015, 6, 42530-42540. [CrossRef]

118. Abdelmegeed, M.A.; Yoo, S.-H.; Henderson, L.E.; Gonzalez, F.J.; Woodcroft, K.J.; Song, B.-J. PPARalpha expression protects male mice from high fat-induced nonalcoholic fatty liver. J. Nutr. 2011, 141, 603-610. [CrossRef]

119. Costet, P.; Legendre, C.; Moré, J.; Edgar, A.; Galtier, P.; Pineau, T. Peroxisome proliferator-activated receptor alpha-isoform deficiency leads to progressive dyslipidemia with sexually dimorphic obesity and steatosis. $J$. Biol. Chem. 1998, 273, 29577-29585. [CrossRef]

120. Ip, E.; Farrell, G.C.; Robertson, G.; Hall, P.; Kirsch, R.; Leclercq, I. Central role of PPARalpha-dependent hepatic lipid turnover in dietary steatohepatitis in mice. Hepatology 2003, 38, 123-132. [CrossRef]

121. Staels, B.; Rubenstrunk, A.; Noel, B.; Rigou, G.; Delataille, P.; Millatt, L.J.; Baron, M.; Lucas, A.; Tailleux, A.; Hum, D.W.; et al. Hepatoprotective effects of the dual peroxisome proliferator-activated receptor alpha/delta agonist, GFT505, in rodent models of nonalcoholic fatty liver disease/nonalcoholic steatohepatitis. Hepatology 2013, 58, 1941-1952. [CrossRef]

122. Francque, S.; Verrijken, A.; Caron, S.; Prawitt, J.; Paumelle, R.; Derudas, B.; Lefebvre, P.; Taskinen, M.-R.; van Hul, W.; Mertens, I.; et al. PPAR $\alpha$ gene expression correlates with severity and histological treatment response in patients with non-alcoholic steatohepatitis. J. Hepatol. 2015, 63, 164-173. [CrossRef] 
123. Braissant, O.; Foufelle, F.; Scotto, C.; Dauça, M.; Wahli, W. Differential expression of peroxisome proliferator-activated receptors (PPARs): Tissue distribution of PPAR-alpha, -beta, and -gamma in the adult rat. Endocrinology 1996, 137, 354-366. [CrossRef]

124. Kliewer, S.A.; Forman, B.M.; Blumberg, B.; Ong, E.S.; Borgmeyer, U.; Mangelsdorf, D.J.; Umesono, K.; Evans, R.M. Differential expression and activation of a family of murine peroxisome proliferator-activated receptors. Proc. Natl. Acad. Sci. USA 1994, 91, 7355-7359. [CrossRef]

125. Auboeuf, D.; Rieusset, J.; Fajas, L.; Vallier, P.; Frering, V.; Riou, J.P.; Staels, B.; Auwerx, J.; Laville, M.; Vidal, H. Tissue distribution and quantification of the expression of mRNAs of peroxisome proliferator-activated receptors and liver $X$ receptor-alpha in humans: No alteration in adipose tissue of obese and NIDDM patients. Diabetes 1997, 46, 1319-1327. [CrossRef]

126. Tugwood, J.D.; Aldridge, T.C.; Lambe, K.G.; Macdonald, N.; Woodyatt, N.J. Peroxisome proliferator-activated receptors: Structures and function. Ann. N. Y. Acad. Sci. 1996, 804, 252-265. [CrossRef]

127. Mukherjee, R.; Jow, L.; Croston, G.E.; Paterniti, J.R. Identification, characterization, and tissue distribution of human peroxisome proliferator-activated receptor (PPAR) isoforms PPARgamma2 versus PPARgamma1 and activation with retinoid $X$ receptor agonists and antagonists. J. Biol. Chem. 1997, 272, 8071-8076. [CrossRef]

128. Girroir, E.E.; Hollingshead, H.E.; He, P.; Zhu, B.; Perdew, G.H.; Peters, J.M. Quantitative expression patterns of peroxisome proliferator-activated receptor-beta/delta (PPARbeta/delta) protein in mice. Biochem. Biophys. Res. Commun. 2008, 371, 456-461. [CrossRef]

129. Kostadinova, R.; Montagner, A.; Gouranton, E.; Fleury, S.; Guillou, H.; Dombrowicz, D.; Desreumaux, P.; Wahli, W. GW501516-activated PPAR $\beta / \delta$ promotes liver fibrosis via p38-JNK MAPK-induced hepatic stellate cell proliferation. Cell Biosci. 2012, 2, 34. [CrossRef]

130. Lee, C.-H.; Olson, P.; Hevener, A.; Mehl, I.; Chong, L.-W.; Olefsky, J.M.; Gonzalez, F.J.; Ham, J.; Kang, H.; Peters, J.M.; et al. PPARdelta regulates glucose metabolism and insulin sensitivity. Proc. Natl. Acad. Sci. USA 2006, 103, 3444-3449. [CrossRef]

131. Sanderson, L.M.; Boekschoten, M.V.; Desvergne, B.; Müller, M.; Kersten, S. Transcriptional profiling reveals divergent roles of PPARalpha and PPARbeta/delta in regulation of gene expression in mouse liver. Physiol. Genom. 2010, 41, 42-52. [CrossRef]

132. Liu, S.; Hatano, B.; Zhao, M.; Yen, C.-C.; Kang, K.; Reilly, S.M.; Gangl, M.R.; Gorgun, C.; Balschi, J.A.; Ntambi, J.M.; et al. Role of peroxisome proliferator-activated receptor $\{$ delta\}/\{beta\} in hepatic metabolic regulation. J. Biol. Chem. 2011, 286, 1237-1247. [CrossRef] [PubMed]

133. Tontonoz, P.; Hu, E.; Graves, R.A.; Budavari, A.I.; Spiegelman, B.M. mPPAR gamma 2: Tissue-specific regulator of an adipocyte enhancer. Genes Dev. 1994, 8, 1224-1234. [CrossRef] [PubMed]

134. Fajas, L.; Auboeuf, D.; Raspé, E.; Schoonjans, K.; Lefebvre, A.M.; Saladin, R.; Najib, J.; Laville, M.; Fruchart, J.C.; Deeb, S.; et al. The organization, promoter analysis, and expression of the human PPARgamma gene. J. Biol. Chem. 1997, 272, 18779-18789. [CrossRef] [PubMed]

135. Boelsterli, U.A.; Bedoucha, M. Toxicological consequences of altered peroxisome proliferator-activated receptor gamma (PPARgamma) expression in the liver: Insights from models of obesity and type 2 diabetes. Biochem. Pharmacol. 2002, 63, 1-10. [CrossRef]

136. Rahimian, R.; Masih-Khan, E.; Lo, M.; van Breemen, C.; McManus, B.M.; Dubé, G.P. Hepatic over-expression of peroxisome proliferator activated receptor gamma2 in the ob/ob mouse model of non-insulin dependent diabetes mellitus. Mol. Cell. Biochem. 2001, 224, 29-37. [CrossRef] [PubMed]

137. Memon, R.A.; Tecott, L.H.; Nonogaki, K.; Beigneux, A.; Moser, A.H.; Grunfeld, C.; Feingold, K.R. Up-regulation of peroxisome proliferator-activated receptors (PPAR-alpha) and PPAR-gamma messenger ribonucleic acid expression in the liver in murine obesity: Troglitazone induces expression of PPAR-gamma-responsive adipose tissue-specific genes in the liver of obese diabetic mice. Endocrinology 2000, 141, 4021-4031. [PubMed]

138. Morán-Salvador, E.; López-Parra, M.; García-Alonso, V.; Titos, E.; Martínez-Clemente, M.; González-Périz, A.; López-Vicario, C.; Barak, Y.; Arroyo, V.; Clària, J. Role for PPAR $\gamma$ in obesity-induced hepatic steatosis as determined by hepatocyte- and macrophage-specific conditional knockouts. FASEB J. 2011, 25, 2538-2550. [CrossRef]

139. Schadinger, S.E.; Bucher, N.L.R.; Schreiber, B.M.; Farmer, S.R. PPARgamma2 regulates lipogenesis and lipid accumulation in steatotic hepatocytes. Am. J. Physiol. Endocrinol. Metab. 2005, 288, E1195-E1205. [CrossRef] 
140. Westerbacka, J.; Kolak, M.; Kiviluoto, T.; Arkkila, P.; Sirén, J.; Hamsten, A.; Fisher, R.M.; Yki-Järvinen, H. Genes involved in fatty acid partitioning and binding, lipolysis, monocyte/macrophage recruitment, and inflammation are overexpressed in the human fatty liver of insulin-resistant subjects. Diabetes 2007, 56, 2759-2765. [CrossRef]

141. Pettinelli, P.; Videla, L.A. Up-regulation of PPAR-gamma mRNA expression in the liver of obese patients: An additional reinforcing lipogenic mechanism to SREBP-1c induction. J. Clin. Endocrinol. Metab. 2011, 96, 1424-1430. [CrossRef]

142. Gavrilova, O.; Haluzik, M.; Matsusue, K.; Cutson, J.J.; Johnson, L.; Dietz, K.R.; Nicol, C.J.; Vinson, C.; Gonzalez, F.J.; Reitman, M.L. Liver peroxisome proliferator-activated receptor gamma contributes to hepatic steatosis, triglyceride clearance, and regulation of body fat mass. J. Biol. Chem. 2003, 278, 34268-34276. [CrossRef] [PubMed]

143. Matsusue, K.; Haluzik, M.; Lambert, G.; Yim, S.-H.; Gavrilova, O.; Ward, J.M.; Brewer, B.; Reitman, M.L.; Gonzalez, F.J. Liver-specific disruption of PPARgamma in leptin-deficient mice improves fatty liver but aggravates diabetic phenotypes. J. Clin. Investig. 2003, 111, 737-747. [CrossRef]

144. Matsusue, K.; Aibara, D.; Hayafuchi, R.; Matsuo, K.; Takiguchi, S.; Gonzalez, F.J.; Yamano, S. Hepatic PPAR $\gamma$ and $\mathrm{LXR} \alpha$ independently regulate lipid accumulation in the livers of genetically obese mice. FEBS Lett. 2014, 588, 2277-2281. [CrossRef]

145. Zhang, Y.-L.; Hernandez-Ono, A.; Siri, P.; Weisberg, S.; Conlon, D.; Graham, M.J.; Crooke, R.M.; Huang, L.-S.; Ginsberg, H.N. Aberrant hepatic expression of PPARgamma2 stimulates hepatic lipogenesis in a mouse model of obesity, insulin resistance, dyslipidemia, and hepatic steatosis. J. Biol. Chem. 2006, 281, 37603-37615. [CrossRef] [PubMed]

146. Wolf Greenstein, A.; Majumdar, N.; Yang, P.; Subbaiah, P.V.; Kineman, R.D.; Cordoba-Chacon, J. Hepatocyte-specific, PPAR $\gamma$-regulated mechanisms to promote steatosis in adult mice. J. Endocrinol. 2017, 232, 107-121. [CrossRef]

147. Panasyuk, G.; Espeillac, C.; Chauvin, C.; Pradelli, L.A.; Horie, Y.; Suzuki, A.; Annicotte, J.-S.; Fajas, L.; Foretz, M.; Verdeguer, F.; et al. PPAR $\gamma$ contributes to PKM2 and HK2 expression in fatty liver. Nat. Commun. 2012, 3, 672. [CrossRef]

148. Noureddin, M.; Anstee, Q.M.; Loomba, R. Review article: Emerging anti-fibrotic therapies in the treatment of non-alcoholic steatohepatitis. Aliment. Pharmacol. Ther. 2016, 43, 1109-1123. [CrossRef]

149. Saile, B.; Ramadori, G. Inflammation, damage repair and liver fibrosis-role of cytokines and different cell types. Z. Gastroenterol. 2007, 45, 77-86. [CrossRef] [PubMed]

150. Siegmund, S.V.; Schwabe, R.F. Endocannabinoids and liver disease. II. Endocannabinoids in the pathogenesis and treatment of liver fibrosis. Am. J. Physiol. Gastrointest. Liver Physiol. 2008, 294, G357-G362. [CrossRef]

151. Di Marzo, V.; Goparaju, S.K.; Wang, L.; Liu, J.; Bátkai, S.; Járai, Z.; Fezza, F.; Miura, G.I.; Palmiter, R.D.; Sugiura, T.; et al. Leptin-regulated endocannabinoids are involved in maintaining food intake. Nature 2001, 410, 822-825. [CrossRef]

152. Kunos, G.; Osei-Hyiaman, D.; Bátkai, S.; Sharkey, K.A.; Makriyannis, A. Should peripheral CB(1) cannabinoid receptors be selectively targeted for therapeutic gain? Trends Pharmacol. Sci. 2009, 30, 1-7. [CrossRef] [PubMed]

153. Jeong, W.-I.; Osei-Hyiaman, D.; Park, O.; Liu, J.; Bátkai, S.; Mukhopadhyay, P.; Horiguchi, N.; Harvey-White, J.; Marsicano, G.; Lutz, B.; et al. Paracrine activation of hepatic CB1 receptors by stellate cell-derived endocannabinoids mediates alcoholic fatty liver. Cell Metab. 2008, 7, 227-235. [CrossRef]

154. Izzo, A.A.; Piscitelli, F.; Capasso, R.; Aviello, G.; Romano, B.; Borrelli, F.; Petrosino, S.; Di Marzo, V. Peripheral endocannabinoid dysregulation in obesity: Relation to intestinal motility and energy processing induced by food deprivation and re-feeding. Br. J. Pharmacol. 2009, 158, 451-461. [CrossRef]

155. Gabbay, E.; Avraham, Y.; Ilan, Y.; Israeli, E.; Berry, E.M. Endocannabinoids and liver disease-review. Liver Int. 2005, 25, 921-926. [CrossRef] [PubMed]

156. Zelber-Sagi, S.; Azar, S.; Nemirovski, A.; Webb, M.; Halpern, Z.; Shibolet, O.; Tam, J. Serum levels of endocannabinoids are independently associated with nonalcoholic fatty liver disease. Obesity 2017, 25, 94-101. [CrossRef] [PubMed]

157. Caraceni, P.; Viola, A.; Piscitelli, F.; Giannone, F.; Berzigotti, A.; Cescon, M.; Domenicali, M.; Petrosino, S.; Giampalma, E.; Riili, A.; et al. Circulating and hepatic endocannabinoids and endocannabinoid-related molecules in patients with cirrhosis. Liver Int. 2010, 30, 816-825. [CrossRef] 
158. Geerts, A. History, heterogeneity, developmental biology, and functions of quiescent hepatic stellate cells. Semin. Liver Dis. 2001, 21,311-335. [CrossRef] [PubMed]

159. Gressner, A.M.; Weiskirchen, R. Modern pathogenetic concepts of liver fibrosis suggest stellate cells and TGF-beta as major players and therapeutic targets. J. Cell. Mol. Med. 2006, 10, 76-99. [CrossRef]

160. Siegmund, S.V.; Uchinami, H.; Osawa, Y.; Brenner, D.A.; Schwabe, R.F. Anandamide induces necrosis in primary hepatic stellate cells. Hepatology 2005, 41, 1085-1095. [CrossRef] [PubMed]

161. Tam, J.; Liu, J.; Mukhopadhyay, B.; Cinar, R.; Godlewski, G.; Kunos, G. Endocannabinoids in liver disease. Hepatology 2011, 53, 346-355. [CrossRef]

162. Siegmund, S.V.; Qian, T.; de Minicis, S.; Harvey-White, J.; Kunos, G.; Vinod, K.Y.; Hungund, B.; Schwabe, R.F. The endocannabinoid 2-arachidonoyl glycerol induces death of hepatic stellate cells via mitochondrial reactive oxygen species. FASEB J. 2007, 21, 2798-2806. [CrossRef]

163. Mackie, K.; Stella, N. Cannabinoid receptors and endocannabinoids: Evidence for new players. AAPS J. 2006, 8, E298-E306. [CrossRef] [PubMed]

164. Berdyshev, E.V. Cannabinoid receptors and the regulation of immune response. Chem. Phys. Lipids 2000, 108, 169-190. [CrossRef]

165. Ross, R.A.; Brockie, H.C.; Pertwee, R.G. Inhibition of nitric oxide production in RAW264.7 macrophages by cannabinoids and palmitoylethanolamide. Eur. J. Pharmacol. 2000, 401, 121-130. [CrossRef]

166. Sugiura, T.; Kondo, S.; Kishimoto, S.; Miyashita, T.; Nakane, S.; Kodaka, T.; Suhara, Y.; Takayama, H.; Waku, K. Evidence that 2-arachidonoylglycerol but not N-palmitoylethanolamine or anandamide is the physiological ligand for the cannabinoid CB2 receptor. Comparison of the agonistic activities of various cannabinoid receptor ligands in HL-60 cells. J. Biol. Chem. 2000, 275, 605-612. [CrossRef]

167. Lambert, D.M.; Vandevoorde, S.; Jonsson, K.-O.; Fowler, C.J. The palmitoylethanolamide family: A new class of anti-inflammatory agents? Curr. Med. Chem. 2002, 9, 663-674. [CrossRef]

168. Wojtalla, A.; Herweck, F.; Granzow, M.; Klein, S.; Trebicka, J.; Huss, S.; Lerner, R.; Lutz, B.; Schildberg, F.A.; Knolle, P.A.; et al. The endocannabinoid N-arachidonoyl dopamine (NADA) selectively induces oxidative stress-mediated cell death in hepatic stellate cells but not in hepatocytes. Am. J. Physiol. Gastrointest. Liver Physiol. 2012, 302, G873-G887. [CrossRef]

169. Hézode, C.; Roudot-Thoraval, F.; Nguyen, S.; Grenard, P.; Julien, B.; Zafrani, E.-S.; Pawlotsky, J.-M.; Pawlostky, J.-M.; Dhumeaux, D.; Lotersztajn, S.; et al. Daily cannabis smoking as a risk factor for progression of fibrosis in chronic hepatitis C. Hepatology 2005, 42, 63-71.

170. Bátkai, S.; Járai, Z.; Wagner, J.A.; Goparaju, S.K.; Varga, K.; Liu, J.; Wang, L.; Mirshahi, F.; Khanolkar, A.D.; Makriyannis, A.; et al. Endocannabinoids acting at vascular CB1 receptors mediate the vasodilated state in advanced liver cirrhosis. Nat. Med. 2001, 7, 827-832.

171. Baldassarre, M.; Giannone, F.A.; Napoli, L.; Tovoli, A.; Ricci, C.S.; Tufoni, M.; Caraceni, P. The endocannabinoid system in advanced liver cirrhosis: Pathophysiological implication and future perspectives. Liver Int. 2013, 33, 1298-1308. [CrossRef]

172. Trebicka, J.; Racz, I.; Siegmund, S.V.; Cara, E.; Granzow, M.; Schierwagen, R.; Klein, S.; Wojtalla, A.; Hennenberg, M.; Huss, S.; et al. Role of cannabinoid receptors in alcoholic hepatic injury: Steatosis and fibrogenesis are increased in CB2 receptor-deficient mice and decreased in CB1 receptor knockouts. Liver Int. 2011, 31, 860-870. [CrossRef] [PubMed]

173. Mallat, A.; Lotersztajn, S. Endocannabinoids as novel mediators of liver diseases. J. Endocrinol. Investig. 2006, $29,58-65$.

174. Yang, Y.-Y.; Lin, H.-C.; Huang, Y.-T.; Lee, T.-Y.; Hou, M.-C.; Wang, Y.-W.; Lee, F.-Y.; Lee, S.-D. Effect of chronic CB1 cannabinoid receptor antagonism on livers of rats with biliary cirrhosis. Clin. Sci. 2007, 112, 533-542. [CrossRef]

175. DeLeve, L.D.; Wang, X.; Kanel, G.C.; Atkinson, R.D.; McCuskey, R.S. Prevention of hepatic fibrosis in a murine model of metabolic syndrome with nonalcoholic steatohepatitis. Am. J. Pathol. 2008, 173, 993-1001. [CrossRef]

176. Domenicali, M.; Caraceni, P.; Giannone, F.; Pertosa, A.M.; Principe, A.; Zambruni, A.; Trevisani, F.; Croci, T.; Bernardi, M. Cannabinoid type 1 receptor antagonism delays ascites formation in rats with cirrhosis. Gastroenterology 2009, 137, 341-349. [CrossRef] 
177. Giannone, F.A.; Baldassarre, M.; Domenicali, M.; Zaccherini, G.; Trevisani, F.; Bernardi, M.; Caraceni, P. Reversal of liver fibrosis by the antagonism of endocannabinoid CB1 receptor in a rat model of CCl(4)-induced advanced cirrhosis. Lab. Investig. 2012, 92, 384-395. [CrossRef]

178. Mukhopadhyay, B.; Cinar, R.; Yin, S.; Liu, J.; Tam, J.; Godlewski, G.; Harvey-White, J.; Mordi, I.; Cravatt, B.F.; Lotersztajn, S.; et al. Hyperactivation of anandamide synthesis and regulation of cell-cycle progression via cannabinoid type 1 (CB1) receptors in the regenerating liver. Proc. Natl. Acad. Sci. USA 2011, 108, 6323-6328. [CrossRef]

179. Teixeira-Clerc, F.; Belot, M.-P.; Manin, S.; Deveaux, V.; Cadoudal, T.; Chobert, M.-N.; Louvet, A.; Zimmer, A.; Tordjmann, T.; Mallat, A.; et al. Beneficial paracrine effects of cannabinoid receptor 2 on liver injury and regeneration. Hepatology 2010, 52, 1046-1059. [CrossRef]

180. Muñoz-Luque, J.; Ros, J.; Fernández-Varo, G.; Tugues, S.; Morales-Ruiz, M.; Alvarez, C.E.; Friedman, S.L.; Arroyo, V.; Jiménez, W. Regression of fibrosis after chronic stimulation of cannabinoid CB2 receptor in cirrhotic rats. J. Pharmacol. Exp. Ther. 2008, 324, 475-483. [CrossRef]

181. Reichenbach, V.; Ros, J.; Fernández-Varo, G.; Casals, G.; Melgar-Lesmes, P.; Campos, T.; Makriyannis, A.; Morales-Ruiz, M.; Jiménez, W. Prevention of fibrosis progression in CCl4-treated rats: Role of the hepatic endocannabinoid and apelin systems. J. Pharmacol. Exp. Ther. 2012, 340, 629-637. [CrossRef]

182. Guillot, A.; Hamdaoui, N.; Bizy, A.; Zoltani, K.; Souktani, R.; Zafrani, E.-S.; Mallat, A.; Lotersztajn, S.; Lafdil, F. Cannabinoid receptor 2 counteracts interleukin-17-induced immune and fibrogenic responses in mouse liver. Hepatology 2014, 59, 296-306. [CrossRef]

183. Rossi, F.; Bellini, G.; Alisi, A.; Alterio, A.; Maione, S.; Perrone, L.; Locatelli, F.; Miraglia del Giudice, E.; Nobili, V. Cannabinoid receptor type 2 functional variant influences liver damage in children with non-alcoholic fatty liver disease. PLoS ONE 2012, 7, e42259. [CrossRef]

184. Koyama, Y.; Brenner, D.A. Liver inflammation and fibrosis. J. Clin. Investig. 2017, 127, 55-64. [CrossRef]

185. Marrone, G.; Shah, V.H.; Gracia-Sancho, J. Sinusoidal communication in liver fibrosis and regeneration. J. Hepatol. 2016, 65, 608-617. [CrossRef]

186. Knittel, T.; Kobold, D.; Saile, B.; Grundmann, A.; Neubauer, K.; Piscaglia, F.; Ramadori, G. Rat liver myofibroblasts and hepatic stellate cells: Different cell populations of the fibroblast lineage with fibrogenic potential. Gastroenterology 1999, 117, 1205-1221. [CrossRef]

187. Iwakiri, Y.; Shah, V.; Rockey, D.C. Vascular pathobiology in chronic liver disease and cirrhosis - current status and future directions. J. Hepatol. 2014, 61, 912-924. [CrossRef]

188. Bernardi, M.; Moreau, R.; Angeli, P.; Schnabl, B.; Arroyo, V. Mechanisms of decompensation and organ failure in cirrhosis: From peripheral arterial vasodilation to systemic inflammation hypothesis. J. Hepatol. 2015, 63, 1272-1284. [CrossRef]

189. Wiest, R.; Groszmann, R.J. The paradox of nitric oxide in cirrhosis and portal hypertension: Too much, not enough. Hepatology 2002, 35, 478-491. [CrossRef]

190. Bosch, J.; Groszmann, R.J.; Shah, V.H. Evolution in the understanding of the pathophysiological basis of portal hypertension: How changes in paradigm are leading to successful new treatments. J. Hepatol. 2015, 62, S121-S130. [CrossRef]

191. Moezi, L.; Gaskari, S.A.; Liu, H.; Baik, S.K.; Dehpour, A.R.; Lee, S.S. Anandamide mediates hyperdynamic circulation in cirrhotic rats via CB(1) and VR(1) receptors. Br. J. Pharmacol. 2006, 149, 898-908. [CrossRef]

192. Varga, K.; Wagner, J.A.; Bridgen, D.T.; Kunos, G. Platelet- and macrophage-derived endogenous cannabinoids are involved in endotoxin-induced hypotension. FASEB J. 1998, 12, 1035-1044. [CrossRef]

193. Liu, J.; Batkai, S.; Pacher, P.; Harvey-White, J.; Wagner, J.A.; Cravatt, B.F.; Gao, B.; Kunos, G. Lipopolysaccharide induces anandamide synthesis in macrophages via CD14/MAPK/phosphoinositide 3-kinase/NF-kappaB independently of platelet-activating factor. J. Biol. Chem. 2003, 278, 45034-45039. [CrossRef]

194. Domenicali, M.; Ros, J.; Fernández-Varo, G.; Cejudo-Martín, P.; Crespo, M.; Morales-Ruiz, M.; Briones, A.M.; Campistol, J.-M.; Arroyo, V.; Vila, E.; et al. Increased anandamide induced relaxation in mesenteric arteries of cirrhotic rats: Role of cannabinoid and vanilloid receptors. Gut 2005, 54, 522-527. [CrossRef]

195. Yang, Y.-Y.; Lin, H.-C. Alteration of intrahepatic microcirculation in cirrhotic livers. J. Chin. Med Assoc. 2015, 78, 430-437. [CrossRef]

196. Orliac, M.L.; Peroni, R.; Celuch, S.M.; Adler-Graschinsky, E. Potentiation of anandamide effects in mesenteric beds isolated from endotoxemic rats. J. Pharmacol. Exp. Ther. 2003, 304, 179-184. [CrossRef] 
197. Yotti, R.; Ripoll, C.; Benito, Y.; Catalina, M.V.; Elízaga, J.; Rincón, D.; Fernández-Avilés, F.; Bermejo, J.; Bañares, R. Left ventricular systolic function is associated with sympathetic nervous activity and markers of inflammation in cirrhosis. Hepatology 2017, 65, 2019-2030. [CrossRef]

198. Gebremedhin, D.; Lange, A.R.; Campbell, W.B.; Hillard, C.J.; Harder, D.R. Cannabinoid CB1 receptor of cat cerebral arterial muscle functions to inhibit L-type Ca2+ channel current. Am. J. Physiol. 1999, 276, H2085-H2093. [CrossRef]

199. Bátkai, S.; Mukhopadhyay, P.; Harvey-White, J.; Kechrid, R.; Pacher, P.; Kunos, G. Endocannabinoids acting at CB1 receptors mediate the cardiac contractile dysfunction in vivo in cirrhotic rats. Am. J. Physiol. Heart Circ. Physiol. 2007, 293, H1689-H1695. [CrossRef]

(C) 2019 by the authors. Licensee MDPI, Basel, Switzerland. This article is an open access article distributed under the terms and conditions of the Creative Commons Attribution (CC BY) license (http://creativecommons.org/licenses/by/4.0/). 